\title{
Interpretation
}

\section{Modeling the interaction between pre-salt seamounts and gravitational failure in salt-bearing passive margins: The Messinian case in the Northwestern Mediterranean Basin}

\begin{tabular}{|c|c|}
\hline Journal: & Interpretation \\
\hline Manuscript ID & INT-2016-0096.R2 \\
\hline Manuscript Type: & 2016-05 Analog modeling as an aid to structural interpretation \\
\hline Date Submitted by the Author: & 20-Nov-2016 \\
\hline Complete List of Authors: & $\begin{array}{l}\text { Ferrer, Oriol; Geomodels Research Institute; University of Barcelona, } \\
\text { Department of Earth and Ocean Dynamics } \\
\text { Gratacós, Oscar; Geomodels Research Institute; University of Barcelona, } \\
\text { Department of Earth and Ocean Dynamics } \\
\text { Roca, Eduard; Geomodels Research Institute; University of Barcelona, } \\
\text { Department of Earth and Ocean Dynamics } \\
\text { Munoz, Josep; Geomodels Research Institute; University of Barcelona, } \\
\text { Department of Earth and Ocean Dynamics }\end{array}$ \\
\hline Keywords: & modeling, salt, interpretation \\
\hline Subject Areas: & $\begin{array}{l}\text { Structural, stratigraphic, and sedimentologic interpretation, Interpretation } \\
\text { concepts, algorithms, methods, and tools }\end{array}$ \\
\hline
\end{tabular}


Interpretation

MODELING THE INTERACTION BETWEEN PRE-SALT SEAMOUNTS AND GRAVITATIONAL FAILURE IN SALT-BEARING PASSIVE MARGINS: THE MESSINIAN CASE IN THE NORTHWESTERN MEDITERRANEAN BASIN

\author{
Oriol Ferrer $^{1}$, Oscar Gratacós ${ }^{1}$, Eduard Roca ${ }^{1}$ and Josep Anton Muñoz ${ }^{1}$ \\ ${ }^{1}$ Geomodels Research Institute. Grup de Geodinàmica i Anàlisi de Conques. Departament de \\ Dinàmica de la Terra i de l'Oceà, Facultat de Ciències de la Terra, Universitat de Barcelona, C/ \\ Martí i Franquès s/n, 08028 Barcelona, Spain \\ E-mails: joferrer@ub.edu, ogratacos@ub.edu, eduardroca@ub.edu, jamunoz@ub.edu \\ Original paper date of submission: $28^{\text {th }}$ June 2016 \\ Revised paper date of submission: $23^{\text {rd }}$ October 2016

\begin{abstract}
\end{abstract}
The Northwest Mediterranean Basin includes a thick Messinian salt sequence composed of three evaporitic units. From these the intermediate unit, which is dominantly composed of halite, acts as a gravitational detachment favoring the downslope failure of the overlying sediments in a thin-skinned deformation regime. As a result, the structure of the margin is characterized by an upper extensional domain with basinward-dipping listric normal faults and a lower contractional domain that accommodates upslope extension by folding, salt inflation or diapir squeezing. Lower to middle Miocene volcanic seamounts (pre-salt reliefs) located at the upper extensional domain locally disrupted the evaporitic units and produced salt flow perturbations. They acted as passive buttresses during the gravitational failure modifying the structural zonation of the margin. 
Using an experimental approach (sandbox models) this study analyses the role played by seamounts during the kinematic evolution of passive margins and how they alter salt flow and suprasalt deformation during gravitational gliding. The experiments show that seamounts locally interrupt the structural zonation of the margin as they hindered downdip salt flow during early deformation. Seamounts initially compartmentalize the margin architecture, resulting in the development of two gravitational sub-systems with two extensional/contractional pairs that are subsequently re-connected when the accumulation of salt analogue upslope of the relief is enough to overthrust it. From this moment, the cover is passively translated downslope as a regional system. The changes in the viscous layer flow velocity related to the dip differences between the flanks and edges of the seamount determine the kinematic evolution of this system. The experiments also provide geometrical constraints to consider during interpretation of these structures, which are commonly poorly imaged in seismic data.

\section{INTRODUCTION}

The downslope failure of salt-bearing passive margins by gravitational gliding or spreading generates broad zones affected by thin-skinned deformation and produces a wellstudied structural zonation (Fig. 1). A typical gravity-driven margin is characterized by wide deformation belts dominated by extensional processes in the upper part linked with a contractional domain in the lower part where the salt pinches-out (e.g., Marton et al., 2000; Brun and Fort, 2004 and 2011; Fort et al., 2004; Hudec and Jackson, 2004 and 2011; Rowan et al., 2004 and 2012, Quirk et al., 2012; Peel, 2014) (Fig. 1). Upslope extension is accommodated by an extensional fault system characterized by basinward-dipping listric faults soling into the salt 
producing salt rollers and rafts (e.g., Duval et al., 1992; Gaullier et al., 1993; Mauduit et al., 1997; Mauduit and Brun, 1998; Brun and Maudit, 2009). In contrast, folds, thrusts, and salt structures (salt-cored anticlines, diapirs or extruding salt sheets) accommodate downslope contraction (e.g., Fort et al., 2004; Hudec and Jackson, 2004; Rowan et al., 2004. Dooley et al., 2007). Depending on the margin scale, a third domain may also develop where the overburden is passively translated basinwards above the salt detachment (Rowan et al., 2004) (Fig. 1).

Pre-salt reliefs that act as flow barriers hindering salt drainage can locally disrupt this classic structural zonation. The reliefs may also act as a nucleation point for secondary structures. These inherited topographic anomalies may be related to pre-salt folds and faults (e.g., Adam and Krézsek, 2012) or to a pre-existing topography related to irregularly eroded surfaces (e.g., Gaullier et al., 1993 and 1996; Maillard et al., 2003) and/or volcanic edifices (e.g., Loncke et al., 2006 and 2010; Guennoc et al., 2011; Granado et al., 2016). The continuity of these reliefs (isolated or linear bodies) and their orientation with respect to the margin slope are key factors during gravitational failure and suprasalt deformation (Cobbold and Szatmari, 1991; Gaullier et al., 1993; Gaullier and Bellaiche, 1996; Loncke et al., 2006 and 2010; Augustin et al., 2014; Feldens and Mitchell, 2015; Dooley and Hudec, this issue; Dooley et al., this issue).

All these observations prompt key questions regarding the kinematic evolution of a saltbearing passive margin with pre-salt reliefs (specifically seamounts):

- How does deformation evolve around pre-salt seamounts during gravitational failure of the margin?

- What are the main factors intrinsic to the geometry of volcanic edifices that control the resulting structural style? 
Using sandbox models and new analysis techniques, this article characterizes salt and suprasalt deformation in response to a pre-salt seamount during gravitational failure of a passive margin. To do so, our experimental programme includes elliptical seamounts with different heights oriented perpendicular to the main salt flow direction. The comparison between experimental results and seismic examples of the North Western Mediterranean Basin depicts that pre-salt seamounts can modify the classical structural zonation of salt-bearing passive margins, hindering salt flow and favoring the development of secondary structures around the relief.

\section{THE LIGURO-PROVENÇAL BASIN (NORTHWESTERN MEDITERRANEAN) \\ Geological setting}

The Northwestern Mediterranean Basin developed between the Iberian-European continental margin and its Corsica-Sardinia conjugate (Fig. 2). It is an Oligocene-Miocene backarc basin that formed during the roll-back of the Maghrebian-Tethys oceanic slab below the Iberia-Europe continental lithosphere (Doglioni et al., 1997; Roca et al., 1999; Cavazza et al., 2004; Schettino and Turco, 2010 among others). In this regional setting, the northwestern margin of the basin was affected by a system of NE-trending extensional faults and shear zones that thinned the Iberian-European continental crust to exhume the lower crust/mantle in the abyssal part of the basin (Chamot-Rooke et al., 1997; Bache et al., 2009; Jolivet et al., 2015) (Fig. 2). The formation of this basin was synchronous with late Oligocene-middle Miocene calc-alkaline magmatism that formed volcanic edifices distributed in the intermediate part of the margin as well as in the surrounding areas (Martí et al., 1992; Maillard and Mauffret, 1993; Beccaluva et al., 1994; Roca, 2001; Guennoc et al., 2011).

The study area is located in the central part of the northwestern margin of this basin between the Gulf of Lions and the Liguro-Provençal Basin (Fig. 2). A regional cross-section 
across this area (Fig. 3) shows the margin architecture with a pre-rift basement that, affected by latest Eocene (?) to early Miocene (Aquitanian) extensional faults, is overlain by a thick succession of uppermost Eocene (?) to present-day deposits (Gorini et al., 1993; Roca, 2001; Jolivet et al., 2015). In this essentially terrigenous succession outlines a major erosive surface (Margin Erosion Surface or MES in Fig. 3) that basinwards is onlapped by Messinian deposits (Lofi et al., 2011a and b). This rugged surface exhibiting subaerial erosion features (Stamplfli and Höcker, 1989) is seismically evidenced by an angular unconformity in the upper part of the margin (Bache et al., 2009). The Messinian deposits include four seismic units ascribed to different lithological compositions: the Clastic Unit (CU) and the "Messinian evaporitic trilogy" formed by the Lower Unit (LU), the Mobile Unit (MU) and the Upper Unit (UU) (Lofi et al., 2011b and Bache et al., 2015).

The Lower Unit (LU) is characterized by a set of continuous reflectors with high amplitude (Lofi et al., 2005 and 2011a; Obone Zue Obame et al., 2011) (Fig. 4). The nature of this unit is still speculative because it has never been sampled. It has been interpreted as clastic turbidites (Lofi et al., 2005 and 2011a) that, according to Roveri et al. (2001 and 2008), may include resedimented gypsum. The LU grades towards the base of the slope to a chaotic and poorly imaged sedimentary body that, integrated by the Clastic Unit (CU), belongs to alluvial fan deposits deriving from margin erosion (Gorini et al., 2015; Cameselle and Urgelés, 2016). Overlying the LU, the intermediate Mobile Unit has transparent seismic facies (Lofi et al., 2005 and 2011a; Obone Zue Obame et al., 2011) (Fig. 4) and has been classically interpreted as consisting dominantly of halite (Nelly, 1994). Finally, the Upper Unit (UU) corresponds to a tabular body made up by high amplitude parallel and continuous reflectors (Lofi et al., 2005 and 2011a; Obone Zue Obame et al., 2011) (Fig. 4). It has been correlated to a layered evaporitic 
sequence and may include dolomitic marls, marls, anhydrites and clastics close to the main canyons (Lofi et al., 2011a).

The deposition of these post-rift Messinian units and the formation of the linked Margin Erosion Surface (MES) have been related to the huge sea-level drop that took place in the Mediterranean during the Messinian Salinity Crisis (Hsü et al., 1973). This sea-level drop was followed by a very fast reflooding in Zanclean (Pliocene) times, which led to the deposition of clastic deposits in a prograding shelf to a deep-sea fan environment that quickly onlapped both the Messinian units and the related unconformity (Fig. 3) (Garcia-Castellanos et al., 2009). These Pliocene to Quaternary deposits derive from the Iberian and European mainland and in the abyssal plain belong to turbidites deposited in the Rhône and Valencia deep sea fan systems (Maldonado et al., 1985; Droz et al., 2006).

The Messinian dips basinwards (Figs. 3 and 4) as a result of the Plio-Quaternary differential thermal subsidence between the Northwestern Mediterranean Basin margins and the basin depocenter (Bessis and Burrus, 1986). This tilting, together with the wedge geometry of the prograding Plio-Quaternary deposits on the upper margin slope, led to the gravitational failure of the sediments deposited above the Messinian salt (MU). Thus, the Messinian Upper Unit (UU) and the Plio-Quaternary deposits were deformed by a combination of gravitational sliding and spreading processes (Cobbold and Szatmari, 1991; Gaullier, 1993; Gaullier and Bellaiche, 1996; Dos Reis et al., 2008). The structural style of these materials is characterized by 1) listric normal growth faults dipping basinwards that sole into the upper part of the MU, 2) contractional detachment folds and squeezed diapirs accommodating upslope extension at the toe of the margin and 3) a passively translated cover without significant deformation between these 
two domains (Gaullier, 1993; Maillard et al., 2003; Gaullier et al., 2006; Dos Reis et al., 2005 and 2008; Loncke et al., 2006; Obone Zue Obame et al., 2011) (Fig. 4a).

The margin architecture of the Liguro-Provençal Basin is similar to other gravitationally failed passive margins with post-rift salt deposits (e.g the South-Atlantic passive margins of Brazil and Angola) (e.g., Marton et al., 2000; Fort et al., 2004; Hudec and Jackson, 2004; Rowan et al., 2004; Quirk et al., 2012). Furthermore, as seen in these margins, pre-salt seamounts are rather common in the entire Northwestern Mediterranean Basin (Sans and Sàbat, 1993; Guennoc et al., 2011; Granado et al., 2016). They are mainly formed by upper Oligocene - middle Miocene calc-alkaline volcanic edifices (Martí et al., 1992; Beccaluva et al., 1994; Roca, 2001; Maillard et al., 2003). Many of these volcanic edifices remained as islands during the whole Messinian Salinity Crisis episode inducing local changes in salt thickness or even disrupting salt continuity (see Fig. 4 for examples of different levels of salt disruption). Such unhomogeneities had a noticeable influence on the structural evolution of the Liguro-Provençal margins during the gravitational failure (Fig. 4).

\section{EXPERIMENTAL METHODOLOGY}

\section{Set-up and procedure}

The experimental program presented in this article includes eight analogue models to analyze how the height of a pre-salt seamount modifies the downslope failure of a salt-bearing passive margin (Table 1). Different models with the same setup have been used to examine the temporal evolution of the system (Table 1). According to the case study these seamounts are located between the extensional and contractional domains, where suprasalt deposits are 
transported basinwards by translation. These models were carried out in a glass-sided deformation rig that was $110 \mathrm{~cm}$-long, $50 \mathrm{~cm}$-wide and $15 \mathrm{~cm}$-deep (Fig. 5). Seamounts were built manually with light blue plasticine in order to facilitate the slicing of the models at the end of the experiment. They were glued to a basal mylar sheet that remained fixed throughout the experiment. The shape and size of the basal seamount section was the same in all the experiments, consisting of a rectangle with a semicircle on each short side (Fig. 5a). All of them had a triangular section in the slope direction with the same height along the rectangular area (Figs. 5a and 5b). The main difference between the seamounts of the different experiments was their height, and consequently the average slope angle of their flanks (Table 1).

Twelve $2.5 \mathrm{~mm}$-thick layers of alternating white and blue dry sand were deposited above the basal mylar sheet simulating uppermost Eocene (?) to upper Miocene (Tortonian) clastic infill of the Liguro-Provençal Basin (Figs. 5b and 5c). Salt equivalent units onlapped the plasticine seamount. They also pinched out upslope against a $3^{\circ}$-downslope dipping erosional surface and terminated downslope against a vertical boundary that acted as a frontal buttress during gravitational failure (Figs. 5a and b).

The mechanical stratigraphy of the experimental evaporitic units was designed according the stratigraphy of the Messinian trilogy in the study area (Fig. 5c). Thus, taking into account that the LU has been never drilled and may contain resedimented gypsum (Roveri et al., 2001 and 2008) we used a $5 \mathrm{~mm}$-thick layer of a $50 \%$ volumetric mixture of sand and a pink polydimethylsiloxane polymer (Rhodosil GUM FB; Dell'Ertole \& Schellart, 2013). This mixture has a higher effective viscosity than pure polymer (the halite analogue) due to the sandy impurities (see Callot et al., 2012 and Cartwright et al., 2012). The halite-rich MU, was simulated using a $10 \mathrm{~mm}$-thick layer of the same polymer but pure and transparent in this case 
Interpretation

(Fig. 5c). Following the methodology proposed by Dooley et al. (2009), different vertical colored polymer plugs located around the plasticine seamount were used as passive markers to trace the flow of the pure polymer during gravitational gliding (Fig. 5a). The mechanical properties of these markers were the same as those of the transparent polymer. Two $2.5 \mathrm{~mm}$-thick layers of white and green silica sand were used as the UU analogue (Fig. 5c). The pre-kinematic package was completed with a $2.5 \mathrm{~mm}$-thick layer of white silica sand covering the entire model and reaching a total thickness of $3 \mathrm{~cm}$ (Fig. 5b).

Gravitational gliding was triggered by tilting the baseboard of the rig to $4.5^{\circ}$ (Fig. $5 \mathrm{~b}$ ). From that moment, additional syn-kinematic layers of dry white and brown silica sand were added at regular two-hours intervals. Both syn- and pre-kinematic sand was poured into the experimental apparatus and then leveled using a mechanical scraper (Krantz, 1991; Lohrmann et al., 2003). Prior to the deposition of each syn-kinematic sand layer, the baseboard was tilted back to horizontal. This slowed the gravitational flow of the polymer and variations in topography during scanning of the modeland deposition of syn-kinematic sand. The regional datum was raised $1.8 \mathrm{~mm}$ by each syn-kinematic layer. After the deposition of each syn-kinematic layer the baseboard was tilted again $4.5^{\circ}$ in the same direction to re-start the gravitational gliding. At the end, the experiments were covered by post-kinematic sand, preserved and serially sectioned into 3 mm-thick vertical slices.

\section{Scaling and mechanical properties of the analogue materials}

The fine-grained (199 $\mu \mathrm{m}$ grain size) silica sand used in the experiments deforms according to Navier-Coulomb failure at moderate-high values of normal stress (Horsfield, 1977). The mechanical properties of the poured sand were determined by a shear box test, resulting in 
an internal friction of $34.6^{\circ}$, a bulk density of $1500 \mathrm{~kg} \mathrm{~m}^{-3}$, a coefficient of internal friction of 0.69 and a low apparent cohesive strength of $55 \mathrm{~Pa}$. In contrast, the pure polymer is a nearNewtonian viscous fluid with a density of $972 \mathrm{~kg} \mathrm{~m}^{-3}$ at room temperature and a viscosity of 1.6 x $10^{-4} \mathrm{~Pa} \mathrm{~s}$ when deformed at a laboratory strain rate of $1.83 \times 10^{-4} \mathrm{~cm} \mathrm{~s}^{-1}$ (Dell'Ertole and Schellart, 2013). The $50 \%$ by volume mixture of sand and polymer has a density of $1550 \mathrm{~kg} \mathrm{~m}^{-3}$ at room temperature and a higher effective viscosity than pure polymer $\left(3.35 \times 10^{-4} \mathrm{~Pa} \mathrm{~s}\right)$ when deformed at the same laboratory strain rate (see Callot et al., 2012 for more information). A summary of these properties and other experimental scaling parameters are shown in Table 2.

\section{Analogue models analysis procedure}

Model's kinematic was documented and subsequently analyzed by means of oblique and overhead time-lapse photographs taken every 30 seconds, in combination with model surface topography recorded before and after the deposition of each syn-kinematic layer using a submillimeter resolution white light scanner (SidioPro from Nub3D).

The vertical serial sections carried out at the end of the experiments were also recorded using high-resolution digital cameras to analyze the variation in the structures along strike. A 4$\mathrm{cm}$ wide section along each side of the experiments was omitted in the analysis to avoid border effects related to the friction between glass sidewalls and the sandpack. High-resolution photographs of the model cross sections were used to reconstruct a 3D voxel model in imageprocessing software allowing the generation of virtual strike and depth slices (see Dooley et al., 2009 for further details). 
Interpretation

\section{EXPERIMENTAL RESULTS}

\section{Baseline model (without seamount)}

We performed a baseline experiment without a seamount (Table 1) to illustrate the main structural features resulting from the tilting of the modeled passive margin. The experimental results illustrate a structural zonation similar to other salt-bearing passive margins, characterized by upslope extension, downslope contraction and an intermediate translational domain (e.g., Marton et al., 2000; Brun and Fort, 2004 and 2011; Fort et al., 2004; Hudec and Jackson, 2004 and 2011; Rowan et al., 2004 and 2012; Quirk et al., 2012; Peel, 2014) (Fig. 6a). As occurs in natural cases, deformation of the sand layers (sedimentary overburden) during tilting is driven by gravitational failure above the pure polymer (regional detachment) as it flows downslope. As a result, the thickness of the polymer decreases upslope in the extensional domain and increases downslope in the contractional domain (Fig. 6a). In contrast, the more viscous LU modeled by the sand and polymer mixture maintained a constant thickness throughout the experiment (Fig. 6a).

A set of basinward dipping listric normal growth faults rooted in the transparent polymer developed in the upslope extensional domain (Duval et al., 1992; Gaullier et al., 1993; Mauduit et al., 1997; Mauduit and Brun, 1998; Brun and Fort, 2004 and 2011; Brun and Mauduit, 2009; Carthwright et al., 2012) (Fig. 6a). While different rollovers grew in the hanging walls of these listric faults, polymer trapped in the footwalls as salt rollers (Duval et al., 1992; Gaullier, 1993; Mauduit and Brun, 1998; Brun and Mauduit, 2009). The strike of these faults was parallel to the upslope polymer pinch-out that constrains the location of the peripheral faults (Fig. 6a). Extensional faults propagated basinward becoming younger downslope. Upslope regional 
extension was accommodated by downslope contraction developing incipient detachment folds at the beginning of gravitational gliding. The growth of these folds was usually aborted by synkinematic sedimentation that strengthens their roofs by thickening during early gravitational gliding. After 3 hours, the outermost fold belt evolved to a simple thrust verging basinwards above the downslope edge of the polymer layer that experience inflation by buttressing (Fig. 6a). In contrast, the overburden of the intermediate translational domain was passively transported downslope above the transparent polymer with no obvious visible deformation (Fig. 6a).

\section{Models with seamounts}

The structural style of the upslope extensional and downslope contractional domains of models with seamounts is very similar to the baseline model (comparison of Figs. 6a and 6c). Whereas different listric normal faults dipping basinwards formed upslope after 6 hours of gravitational gliding, a detached fold belt evolving into a simple thrust developed downslope in the salt pinch-out (Fig. 6c). If gravitational gliding continues (e.g., models with 18 hours of gravitational gliding, Fig. 6b), the extensional domain widens, with younger faults progressively developing downslope. The increase of extensional deformation is balanced downslope by a second thrust developed in a break-back sequence and by polymer inflation (Fig. 6b).

However, the main difference between models with and without a seamount is the interruption of polymer flow by pre-salt reliefs. The kinematic evolution of the overburden in models with a seamount clearly depends on the position of their summit lying below or above the top salt at the beginning of the experiment. Thus, the seamount partially blocks salt flow when 
Interpretation

their summit lies below the top salt (Fig. 6b). In contrast, the salt flow is totally blocked when the summit lies above the top salt (Fig. 6c). This entails the development of secondary structures around the seamount that in the second case disrupts the continuity of the translational domain (Fig. 6c). The following sections of the manuscript introduce the main structural elements as well as the kinematic evolution of both cases.

Seamount does not fully block salt flow - summit lies below top salt

In the case whereby the seamount lies below top salt cover deformation is characterized by a regional extensional-contractional system that continually glides basinwards throughout the experiment (Fig. 6b). At the beginning of the gravitational failure, the seamount partially opposed to polymer flow and hampered its drainage. Buttressing favored polymer inflation upslope of the seamount slightly raising the top of the initial regional datum (Fig. 7a). Coeval with polymer inflation, the development of a syncline downslope of the seamount occurred in conjunction with the consequent thinning of the pure polymer layer (Fig. 7a). An incipient collapse graben may develop during the early deformation at the crest of the anticline (Fig. 7b). Syn-kinematic layers onlapped the pre-kinematic unit above the syncline and progressively offlapped upslope of the seamount due to polymer inflation (Fig. 7a).

As the model evolved downdip polymer flow fed the anticline that was gradually translated downdip (Fig. 7b). The interaction between the syn-kinematic sedimentation and the anticline growth produced an erosive unconformity that climbed through younger syn-kinematic units. Basinwards this unconformity evolved into a paracomformity (Fig. 7b). Taking into account that 
the seamount is fixed during the experiments, the upslope migration of syn-kinematic depocenters and onlaps (Fig. 7) indicates that the basin depocenter maintain a relatively fixed position during gravitational gliding. Thus, for the last stages of deformation, the syn-kinematic sand layers filling the syncline were deposited above uplifted areas previously located upslope of the seamount. This is noticed because older syn-kinematic layers where absent or pinched-out downslope against the unconformity (Fig. 7b).

\section{Seamount fully blocks salt flow - summit lies above top salt}

In this situation, the height of the seamount lying above top salt plays a key role in the regional structural style and the kinematic evolution of the model. In order to understand how is the temporal evolution when seamounts fully blocks salt flow, we used different models with the same initial setup but with different lengths (Table 1 and Fig. 8). The variation in the ratio between seamount height and top salt throughout the experiment highlights two distinct evolutionary stages.

During the first stage, the seamount locally interrupts the lateral continuity of the pure polymer layer and compartmentalizes the three-domain gravitational system into two extensionalcontractional sub-systems (Figs. 6c, 8a and $9 b$ to d). Updip extension was accommodated upslope of the seamount by polymer thickening and the development of a downdip-verging thrust (structure 1 in Fig. 8a). A "hanging-wall terrace" formed by the UU was preserved in the footwall of this thrust attached to the seamount. Thrust propagation uplifted the regional controlling the offlap terminations of the syn-kinematic layers in the backlimb of the hanging 
wall anticline (Fig. 8a). In contrast, a major listric normal fault rooted in the pure polymer flank (structure 2 in Fig. 8a) controlled the development of the basin. Thin-skinned extension triggered the rise of reactive ridges along the extensional faults of the basin (Vendeville and Jackson, 1992; Hudec and Jackson, 2011) (Figs. 8a, 9b to 9d and 10b). These ridges converged towards the central part of the basin leading to an active diapir (Fig. 9c). At the last stages of this first episode the pure polymer layer was continuous below the basin, being practically depleted below the hanging wall of the main extensional fault (structure 2 in Fig. 8a). This prevented the downdip flow of the pink layer (sand-polymer mixture). The forelimb of the hanging wall anticline above the seamount collapsed when the overburden reached the summit of the seamount at the end of this first stage. As a consequence debrites deposits were incorporated to the third syn-kinematic layer of the basin (greenish sand on Fig. 8a).

The second stage begins when top salt ride above the seamount and it was overthrusted by the upslope cover using the pure polymer as a detachment (Figs. 8b, 8c and 9e to 9h). At this point, the kinematics of the model dramatically changes and the two gravitational sub-systems are reconnected. The time sequence evolution of figures $8 \mathrm{~b}$ and $8 \mathrm{c}$ shows how after re-connection the entire margin is translated downslope as a unique extensional-contractional system. As the model evolved, the structure around the seamount becomes much more complex with progressive overlap of the contractional and extensional zones downslope of the relief (Fig. 8b and 8c). Downslope of the seamount, the structural style dramatically changed after polymer depletion (Figs. 8b, 10b and 10f). This is the beginning of a gradual attenuation of the pre-existing structures (Fig. 9d to 9h). After welding, the basin was passively transported downslope above the main normal fault that initially developed attached to the downslope flank of the seamount (structure 2 in Fig. 8). Although the pink layer has a higher effective viscosity than pure 
polymer, the total depletion of the pure polymer triggered the flow of the sand-polymer mixture that acted as a less efficient detachment (Figs. 8b, 8c, 10f and 10g).

The combined effect of cover overthrusting and welding also forced the development of a gravitationally linked contractional zone downslope of the seamount (Figs. 8b, 10b and 11). The structural style of this contractional zone results from the interaction between the height difference between the crest of the anticline above the seamount and the basin as well as from the syn-kinematic sedimentation rate. The most important height difference occurred during the early overthrusting and was coeval to the development of the first thrust and the maximum development of debrites (layers 3 and 4 of Fig. 11). The gradual height attenuation between the crest of the anticline and the adjacent basin during overthrusting resulted in a progressive reduction of the debrites volume (layers 5 and 6 of Fig. 11). The syn-kinematic sedimentation rate applied to our models aborted the growth of these folds and thrusts. A prominent angular unconformity developed as a result of the interaction between the growth of the gravitational linked contractional structures and the sedimentation rate (dashed lines in Figs. 8 and 11). The syn-kinematic layers of the basin onlapped against the partly eroded overthrusted syn-kinematic layers and the offlaps developed upslope of the seamount (Fig. 11).

\author{
DISCUSSION
}

\title{
What is the impact of a pre-salt seamount on the regional structure of a salt-bearing passive margin?
}


Interpretation

The presence of linear pre-salt seamounts in a salt-bearing passive margin can modify the regional structure because seamounts interrupt the continuity of the evaporitic unit. Depending on the height differences between the seamount summit and the top of the viscous layer, this disruption can lead to significant changes in the classical structural zonation of such margins. Seamounts initially hinder salt drainage during early gravitational failure by acting as a passive buttress to flow. Our physical models show that when the summit of the seamount lies below top salt (experiments 1 and 1a, Table 1), the cover glides downslope as a unique extensionalcontractional system encompassing an intermediate translational zone. The syn-kinematic units of the translational domain show significant thickness variations related to the development of a basin downslope of the seamount (Figs. 6b and 7). In contrast, two well-differentiated gravitational sub-systems with upslope extension and downslope contraction develop when the summit of the seamount is located near or above the top of the polymer layer (experiments 2 to 5, Table 1) (Fig. 6c). Here, the structural style of both pairs is slightly different. Although listric faults develop in the extensional domain of both sub-systems, these differ on number, spacing and slip (Fig. 6c). These differences are basically induced by the thickness of the pure polymer prior to the gravitational deformation (Fig. 6c) and the slope angle of the seamount flank (Figs. 8 and 12b, Table 1). Similarly, the dip of the thrusts developed upslope of the seamount is steeper that the thrusts related to the pure polymer downslope pinch-out (Fig. 6c). Here the main control factor is the relative height of the seamount summit above the top of the pure polymer at the beginning of the gravitational gliding. Both contractional sub-systems are extremely different for model 6 (Table 1, Fig. 12) in which the distance between the summit of the seamount and the top of the polymer does not allow cover overthrusting. As a result, buttressing produced by the 
Interpretation

upslope seamount flank enhanced the development of a backthrust with an associated piggy-back basin (Fig. 12).

\section{How do seamounts affect the salt flow pattern during gravitational failure of the margin?}

The experimental programme presented in this article depicts how a pre-salt relief hinders drainage of a viscous polymer induced by tilting. A contour map of the top of the pure polymer illustrates the zones where polymer was depleted or accumulated during gravitational gliding (Fig. 13a). It clearly shows how the polymer thickened upslope of the seamount before being able to flow over the summit and carries the roof with it as an overthrust (white blue colors above the black dashed line). This map also shows how a passive diapir developed downslope of the seamount (Fig. 13a). This diapir is surrounded by four welded basins separated by arcuate polymer ridges. The colored polymer plugs introduced in the pure polymer around the seamounts (Fig. 5a) allowed us to track the effect of the seamounts on polymer flow during gravitational gliding (Fig. 13). Depending on their location, these cylindrical markers were deformed in different ways. The outermost, located symmetrically at both ends of the seamount (blue and red markers with numbers 1, 5, 6 and 10 in Fig. 13b or blue polymer in Fig. 10a), were essentially deformed following straight trajectories parallel or slightly oblique to the regional dip direction. The top of these markers is the most seaward part of them, depicting a strong component of Couette flow related to the shearing of the pure polymer by downslope translation of the overburden (Fig. 10a).

In contrast, the polymer plugs around the seamount reveal a complex streamlines patterns and related flow velocities as suggested by areas of plug inflation and deflation (Fig. 13b). The deformation of the central blue marker located updip of the seamount is controlled by the 
seamount height and the initial thickness of pure polymer. So, when the seamount summit lies above the top polymer (e.g., experiment 6, Fig. 12) the polymer cannot flow over it and the central marker deforms with a divergent flow pattern. Two horns with opposite streamline directions developed parallel to the seamount trend. These morphological variations imply significant variations in flow velocity that progressively decrease until the polymer reaches the summit of the seamount. An increase in flow velocity took place during overthrusting as a consequence of the progressive polymer thickening above the seamount. The yellow markers located upslope of the seamount (numbers 2 and 4 in Fig. 13b), show how the streamlines avoid the seamount using a curved trajectory or bypass. This divergent pattern considerably reduces the distance between streamlines, indicating an increase in flow velocity. Streamlines show a convergent pattern once the yellow markers surpass the seamount (Fig. 13). This is probably constrained by the development of the basin downslope of the seamount (Fig. 13b). On a different way, the sinking of the basin and the gravitational gliding stretched the three markers downslope of the seamount (numbers 6,7 and 8 in Fig. 13). At the begining of gravitational gliding they show a marked Couette flow component (e.g., red marker on Fig. 7b). As gravitational gliding progressed, the polymer initially below the basin was expulsed downdip. The pressurized polymer moved towards the passive diapir - pressure release - showing a convergent streamlines trajectory. Figure $13 \mathrm{~b}$ shows how the red markers followed the ridges between the welded areas to feed the central passive diapir. In the cross-section of figure $13 \mathrm{c}$ these red markers show a plume shape that reaches the surface of the diapir. The development of this plume was forced by the inward injection of the transparent polymer during the rise of the passive diapir (Dooley et al., 2009). Downslope of the diapir, the red markers show a divergent flow pattern following the ridges between the welded areas (Fig. 13b). 


\section{COMPARISON WITH THE LIGURO-PROVENÇAL BASIN}

The gravitational system documented in our baseline model (Fig. 6a) is broadly similar to the geometries of the study area when seamounts are absent or their summit do not reaches the Messinian salt (Fig. 4a). In both cases, the salt unit is continuous and flows downdip. A set of listric normal faults dipping basinwards developed in the upper part of the margin (Gaullier, 1993; Gaullier et al., 1993; Reis et al., 2008) (Fig. 4a). Upslope extension is accommodated downslope by detachment folds and squeezed diapirs (Gaullier, 1993; Gaullier and Bellaiche, 1996; Reis et al., 2005 and 2008) (Fig. 4a). In between the practically undeformed overburden is gravitationally translated using the MU as a detachment (Gaullier, 1993; Reis et al., 2008) (Fig. 4a). Although the structural style of the extensional system is similar (Figs. 10b and 13a), the contractional system differs greatly between nature and the experiments (compare Figs. $4 \mathrm{a}$ and 6a). While detachment folds and squeezed diapirs are common in the Liguro-Provençal Basin (Fig. 4a), buckle folds were quickly aborted in our physical models evolving into different thrusts emplaced in a break-back sequence (Fig. 6b). The early detachment folds were buried due to the high sedimentation rate applied to our models developing a thick and strong overburden that inhibited folding. In contrast, thrust development is basically constrained by the downslope vertical edge of the salt basin, which acts as a nucleation point for the first thrust. However, in the Liguro-Provençal Basin, there is no downdip salt pinch-out, except towards the Balearic Islands and Corsica (Lofi et al., 2011a). Elsewhere, the salt layer is continuous from Marseille to Algiers (e.g., Gaullier and Bellaiche, 1996; Dos Reis et al., 2005; Lofi et al., 2011a). 
Interpretation

Our physical models predict that the presence of seamounts in the translational domain of the Liguro-Provençal Basin could significantly impact the margin architecture (Figs. 4b and 4c). The effect of seamounts on the margin deformation occurs at two different scales. At a regional scale, they could interrupt the continuity of the translational domain, resulting in the development of two gravitational sub-systems (Figs. 4b and 4c). In addition, they locally control the development of contractional and extensional structures upslope and downslope of the seamount respectively (Figs. $4 \mathrm{~b}$ and $\mathrm{c}$ ). The structural style of the upslope structures clearly differs between experiments and seismic data. Salt inflated areas (Fig. 4b) or asymmetric buckle folds (Fig. 4c) have been interpreted upslope seamounts in seismic profiles. In our experiments polymer inflates until it can flow over the seamount (Figs. 8a and 8b). Downdip-verging thrusts form in the overburden as the roof is carried over the pre-salt high. On the other hand, a backthrust develops when the salt inflated area upslope the seamount cannot reach the summit of the relief (experiment 6, Table 1, Fig. 12). Despite this, no thrust has been interpreted upslope of the seamounts in the studied dataset. Taking into account the limitations of $2 \mathrm{D}$ seismic for the characterization of complex tridimensional structures, the lack of thrusts may be related to several factors: 1) the amount of shortening (less than in our experiments); 2) the shape of the seamount (the buttressing for isolated circular seamounts may be small or non-existent); 3) the volume of salt available upslope of the seamounts; 4) the composition of the halite of the MU that could become less pure at the basin margin; or 5) the deformation rate of evaporites (slower for the Liguro-Provençal Basin due to progressive tilting but constant throughout our experiments). 
Additionally, the LU has been never sampled in the Liguro-Provençal Basin and its composition is speculative (clastic turbidites and resedimented gypsum, according to Roveri et al. 2001 and 2008). The approximation we have used as analogue of this unit is a material with a higher effective viscosity than pure polymer based on a mixture of sand and polymer (Callot et al., 2012). However, the experiments with a greater gravitational gliding clearly show that after pure polymer depletion, the weight of the basin triggered the deformation of this material (Figs. $8 \mathrm{~b}$ and $8 \mathrm{c}$ ). The seismic profiles studied in this project clearly show that the LU remains undeformed in the Liguro-Provençal Basin. This could be related to the mechanical properties of this unit, which are likely closer to a brittle behavior.

\section{CONCLUSIONS}

The presence of pre-salt relief in the form of a seamount can modify the three domain structural zonation of salt-bearing passive margins developing two gravitational sub-systems separated by the seamount. These are characterized by upslope extension and downslope contraction

The structural style and kinematics of both margin-wide and local structures may change during gravitational gliding if the amount of salt upslope of the seamount is sufficient to overtake the relief. Thus, depending on the seamount height with respect the top of the evaporitic unit, seamounts can act as temporary barriers during margin evolution, resulting in two different stages. During the first stage, the seamount initially hinders salt flow, forcing salt migration around the relief. As a consequence of the buttress upslope of the seamount, a thrust develops 
Interpretation

and gradually uplifts the cover. When the cover reaches the height of the relief, the seamount is overthrusted, and falls rapidly downslope along the seamount flank. A significant increase in salt flow velocity occurs coeval with overthrusting. The development of a primary weld below the basin downslope of the seamount and the flow velocity decrease that occurs at the edge of the seamount favors the formation of an fold and thrust system.

The seamounts hinder salt flow, forcing the development of a divergent pattern in the polymer streamlines surrounding the relief during gravitational gliding. Streamlines deviation also occur where there are diapirs allowing salt to escape vertically from beneath the basins. In contrast, streamlines in areas without seamounts or diapirs describe dominantly linear traces parallel to the dip direction of the passive margin.

The experimental results included in this manuscript provide a set of geometrical constraints that can be used in seismic interpretation of similar structures in margins with pre-salt seamounts (e.g., Eastern Mediterranean, Red Sea, offshore Morocco). Because the seismic dataset available for the study area is $2 \mathrm{D}$, analogue models also allow us to infer the threedimensional geometry of the supra-salt structures.

\section{ACKNOWLEDGMENTS}

OF dedicates this article to the memory of M.P.A. Jackson who guided my first steps in salt tectonics. We gratefully acknowledge V. Gaullier, B.C. Vendeville and T. Dooley for their 
helpful comments and reviews. This research was funded by the SALTECRES project (CGL2014-54118-C2-1-R MINECO/FEDER, UE) as well as the Grup de Recerca de Geodinàmica $i$ Anàlisi de Conques (2014SRG467). The Geomodels Analogue Modeling Laboratory was supported by a Scientific Infrastructure (UNBA08-4E-006) co-funded by the European Regional Development Fund of the Ministerio de Ciencia e Innovación of the Spanish Government and Statoil. Paradigm ${ }^{T M}$, Midland Valley and IHS are also acknowledged for providing Gocad, Move and Kingdom Suite softwares.

\section{REFERENCES}

Adam, J., and C. Krézsek, C., 2012, Basin-scale salt tectonic processes of the Laurentian Basin, Eastern Canada: insights from integrated regional 2D seismic interpretation and 4D physical experiments, in G.I. Alsop, S.G. Archer, A.J. Hartley, N.T. Grant, and R. Hodgkinson, eds., Salt Tectonics, Sediments and Prospectivity: Geological Society, London Special Publications, 363, 331-360.

Augustin, N., C. W. Devey, F.M. Van der Zwan, P. Feldens, M. Tominaga, R.A. Bantan, and T. Kwasnitschka, 2014, The rifting to streading transition in the Red Sea: Earth and Planetary Science Letters, 395, 217-230.

Bache, F., J.-P. Olivet, M. Rabineau, J. Baztan, D. Aslanian and J.-P. Suc, 2009, Messinian erosional and salinity crises: View from the Provence Basin (Gulf of Lions, Western Mediterranean): Earth and Planetary Science Letters, 286, 1-2, 139-157.

Bache, F., J. Gargani, J.-P. Suc, C. Gorini, M. Rabineau, S.-M. Popescu, E. Leroux, D. Do Couto, G. Jouannic, J.-L. Rubino, J.-L. Olivet, G. Clauzon, A.T. Dos Reis and D. Aslanian, 
Interpretation

2015, Messinian evaporite depositon during sea level rise in the Gulf of Lions (Western Mediterranean): Marine and Petroleum Geology, 66, 262-277.

Beccaluva, L., M. Coltorti, R. Galassi, G. Macciotta and F. Siena, 1994, The Cainozoic calcalkaline magmatism of the western Mediterranean and its geodynamic significance: Bolletino di Geofisica Teorica ed Applicata, 36, 293-309.

Bessis, F., and J. Burrus, 1986, Étude de la subsidence de la marge du Golfe du Lion (Mediterranée Occidentale) : Bulletin des Centres de Recherche et Exploration-Production ElfAquitaine, 10, 123-141.

Brun, J.-P., and X. Fort, 2004, Compressional salt tectonics (Angolan margin): Tectonophysics, 382, 129-150.

Brun, J.-P., and X. Fort, 2011, Salt tectonics at passive margins: Geology versus models: Marine and Petroleum Geology, 28, 1123-1145.

Brun, J.-P., and T.P.O. Mauduit, 2009, Salt rollers: structure and kinematics from analogue modelling: Marine and Petroleum Geology, 26, 249-258.

Callot, J-P., V. Trocmé, J. Letouzey, E. Albouy, S. Jahani, S. Sherkati, 2012, Pre-existing salt structures and the folding of the Zagros Mountains, in G.I. Alsop, S.G. Archer, A.J. Hartley, N.T. Grant, and R. Hodgkinson, eds., Salt Tectonics, Sediments and Prospectivity: Geological Society, London Special Publications, 363, 545-561.

Cameselle, A.L., and R. Urgelés, 2016, Large-scale margin collapse during Messinian early sea-level drawdown: the SW Valencia trough, NW Mediterranean: Basin Research doi: $10.1111 /$ bre. 12170 
Cartwright, J., M.P. Jackson, T. Dooley, and S. Higgins, 2012, Strain partitioning in gravity-driven shortening of a thick, multilayered evaporite sequence, in G.I. Alsop, S.G. Archer, A.J. Hartley, N.T. Grant, and R. Hodgkinson, eds., Salt Tectonics, Sediments and Prospectivity: Geological Society, London Special Publications, 363, 449-470.

Cavazza, W., F. Roure, W. Spakman, G.M. Stamplfli, and P.A. Ziegler, 2004, The TRANSMED Atlas - The Mediterranean Region from Crust to Mantle: Springer, BerlinHeidelberg.

Chamot-Rooke, N., F. Jestin, and J.M. Gaulier, 1997, Constraints on the Moho depth and crustal thickness in the Liguro-Provençal Basin from 3D gravity inversion: Geodynamic implications: Revue de l'Institut Français du Pétrole, 52, 557-583.

Cobbold, P.R. and P. Szatmari, 1991, Radial gravitational gliding on passive margins: Tectonophysics, 188, 249-289.

Dell'Ertole, D., and W.P. Schellart, 2013, The development of sheath folds in viscously stratified materials in simple shear conditions: an analogue approach: Journal of Structural Geology, 56, 129-141.

\author{
Doglioni, C., E. Gueguen, F. Sàbat, and M. Fernández, 1997, The Western Mediterranean \\ extensional basins and the Alpine Orogen: Terra Nova, 9, 109-112.
}

Dooley, T.P., M.P.A. Jackson, and M.R. Hudec, 2007, Initiation and growth of salt-based thrust belts on passive margins: results from physical models: Basin Research, 19, 165-177. 
Interpretation

Dooley, T.P., M.P.A. Jackson, and M.R. Hudec, 2009, Inflation and deflation of deeply buried salt stocks during lateral shortening: Journal of Structural Geology, 31, 582-600.

Dooley, T.P., M.R. Hudec, D. Garruthers, M.P.A. Jackson and G. Luo (in this issue), The effects of base-salt relief on salt flow and suprasalt deformation patterns - Part 1: Flow across simple steps in the base of salt: Interpretation,

Dooley, T.P. and M.R. Hudec (in this issue), The effects of base-salt relief on salt flow and suprasalt deformation patterns - Part 2: Application to the Eastern Gulf of Mexico: Interpretation,

Dos Reis, A.T., C. Gorini, and A. Mauffret, 2005, Implications of salt-sediment interactions for the architecture of the Gulf of Lions deep-water sedimentary systems - Western Mediterranean: Marine and Petroleum Geology, 22, 713-746.

Dos Reis, A.T., C. Gorini, W. Weibull, R. Perovano, M. Mepen, and É. Ferreira, 2008, Radial gravitational gliding indicated by subsalt relief and salt-related structures: the example of the Gulf of Lions, Western Mediterranean: Revista Brasileira de Geofísica, 26, 347-365.

Droz, L., A.T. Dos Reis, M. Rabineau, S. Berné, and G. Bellaiche, 2006, Quaternary turbidite systems on the northern margins of the Balearic Basin (Western Mediterranean): A synthesis: Geo-Marine Letters, 26, 347-359.

Duval, B., Cramez, C., and M.P.A. Jackson, 1992, Raft tectonics in the Kwanza Basin, Angola: Marine and Petroleum Geology, 9, 389-404. 
Feldens, P., and N.C. Mitchell, 2015, Salt flows in the Central Red Sea, in N.M.A. Rasul, and I.C.F. Stewart, eds., The Red Sea: Springer Earth System Sciences. Berlin Heidelberg, Springer, 205-218.

Fort, X., J.-P. Brun, and F. Chauvel, 2004, Salt tectonics on the Angolan margin, synsedimentary deformation processes: AAPG Bulletin, 88, 1523-1544.

Garcia-Castellanos, D., F. Estrada, I. Jiménez-Munt, C. Gorini, M. Fernández, J. Vergés, and R. De Vicente, 2009. Catastrophic flood of the Mediterranean after the Messinian salinity crisis: Nature, 462 (7274), 779-781.

Gaullier, V., 1993, Diapirisme salifère et dynamique sédimentaire dans le bassin LiguroProvençal : Thèse de $3^{\text {éme }}$ cycle, Université de Paris 6, 327pp.

Gaullier, V., J-P. Brun, G. Guérin, H. Lecanu, 1993. Raft tectonics: the effect of residual topography below a salt décollement: Tectonophysics, 228, 363-381.

Gaullier, V., and G. Bellaiche, 1996, Diapirisme liguro-provençal : les effets d'une topographie résiduelle sous le sel messinien. Apports de la módelisation analogique : Comptes Rendus Académie Sciences, Paris, 322 (Série IIa), 213-220.

Gaullier, V., B.C. Vendeville, H. Huguen, J. Déverchère, L. Droz, A. Domzig, E. Obone Zue Obame, K. Yelles, and the MARADJA and PROGRES Scientific Parties, 2006, Role of thick-skinned tectonics on thin-skinned salt tectonics in the Western Mediterranean: A comparison between the Algerian and North-Balearic basins: European Geosciences Union General Assembly, Vienna, Abstract volume 8, 1029-7006. 
Interpretation

Gorini, C., A. Le Marrec, and A. Mauffret, 1993, Contribution to the structural and sedimentary history of the Gulf of Lions (Western Mediterranean), from the ECORS profiles, industrial seismic profiles and well data: Bulletin de la Société Géologique de France, 164, 353363.

Gorini, C., L. Montadert, and M. Rabineau, 2015, New imaging of the salinity crisis: Dual Messinian lowstand megasequences recorded in the deep basin of both the eastern and western Mediterranean: Marine and Petroleum Geology, 66, 278-294.

Granado, P., R. Urgelés, F. Sàbat, E. Albert-Villanueva, E. Roca, J.A. Muñoz, N. Mazzuca, and R. Gambini, in press, Geodynamic framework and hydrocarbon plays of a salt giant: The North Western Mediterranean Basin: Petroleum Geoscience.

Guennoc, P., J.-P. Réhault, and I. Thinon, 2011, West-Corsica Margin, in Seismic atlas of the "Messinian Salinity Crisis" markers in the Mediterranean and Black Seas. Lofi et al., 2011. Commission for the Geological Map of the World (CGMW): Mémoires de la Société Géologique de France, 179, 46-48.

Horsfield, W.T., 1977, An experimental approach to basement controlled faulting: Geologie en Mijnbouw, 56, 363-370.

Hudec, M.R. and M.P.A. Jackson, 2004, Regional restoration across the Kwanza Basin, Angola: Salt tectonics triggered by repeated uplift of a metastable passive margin: AAPG Bulletin, 88, 971-990. 
Hudec, M.R. and M.P.A. Jackson, 2011, The salt mine: a digital atlas of salt tectonics: The University of Texas at Austin, Bureau of Economic Geology, Udden Book Series No. 5, AAPG Memoir 99, 305 p.

Hsü, K.J., W.B.F. Ryan, and M.B. Cita, 1973, Late Miocene desiccation of the Mediterranean: Nature, 242, 240-244.

Jolivet, L., C. Gorini, J. Smit, and S. Leroy, 2015, Continental breakup and the dynamics of rifting in back-arc basins: The Gulf of Lion margin: Tectonics, 34, 662-679. doi: $\underline{10.1002 / 2014 \mathrm{TC} 003570 .}$.

Krantz, R.W., 1991, Measurements of friction coefficients and cohesion for faulting and fault reactivation in laboratory models using sand and sand mixtures: Tectonophysics, 188, 203207.

Lofi, J., C. Gorini, S. Berné, G. Clauzon, T. Dos Reis, W.B.F. Ryan, and M.S. Steckler, 2005, Erosional processes and paleo-environmental changes in the western Gulf of Lions (SW France) during the Messinian Salinity Crisis: Marine and Petroleum Geology, 217, 1-30.

Lofi, J., F. Sage, J. Déverchère, L. Loncke, A. Maillard, V. Gaulier, I. Thinon, H. Gillet, P. Guennoc, and C. Gorini, 2011a, Refining our knowledge of the Messinian Salinity Crisis records in the offshore domain through multi-site seismic arrays: Bulletin de la Société Géologique de France, 182, 163-180.

Lofi, J., J. Déverchère, V. Gaulier, H. Gillet, C. Gorini, P. Guennoc, L. Loncke, A. Maillard, F. Sage, and I. Thinon, 2011b, Seismic atlas of the "Messinian Salinity Crisis" markers 
in the Mediterranean and Black Seas. Commission for the Geological Map of the World (CGMW) : Mémoires de la Société Géologique de France, 179, 72pp. 1CD.

Lohrmann, J., N. Kukowski, J. Adam, and O. Oncken, 2003, The impact of analogue material properties on the geometry, kinematics, and dynamics of convergent sand wedges: Journal of Structural Geology, 25, 1691-1771.

Loncke, L., V. Gaullier, J. Mascle, B.C. Vendeville, and L. Camera, 2006, The Nile deep-sea fan: an example of interacting sedimentation, salt tectonics and inherited subsalt paleotopographic features: Marine and Petroleum Geology, 23, 297-315.

Loncke, L., B.C. Vendeville, V. Gaullier, and J. Mascle, 2010, Respective contributions of tectonic and gravity-driven processes on the structural pattern in the Eastern Nile deep-sea fan : insights from physical experiments: Basin Research, 22, 765-782.

Maillard, A., and A. Mauffret, 1993, Structure et volcanisme dans la fosse de Valence (Méditerranée Nord-occidentale) : Bulletin de la Société Géologique de France, 164, 338-365.

Maillard, A., V. Gaullier, B.C. Vendeville and F. Odonne, 2003, Influence of differential compaction above basement steps on salt tectonics in the Ligurian-Provençal Basin, northwest Mediterranean: Marine and Petroleum Geology, 20, 13-27.

Maldonado, A., H. Got, A. Monaco, S. O’Connell, and L. Mirabile, 1985, Valencia Fan (northwestern Mediterranean): Distal deposition fan variant: Marine Geology, 62, 295-319. 
Martí, J., J. Mitjavila, E. Roca, and A. Aparicio, 1992, Cenozoic magmatism of the Valencia Through (Western Mediterranean): relationship between structural evolution and volcanism: Tectonophysics, 203, 145-165.

Marton, L.G., G.C. Tari, and C.T. Lehmann, 2000, Evolution of the Angolan passive margin, West Africa, with emphasis on post-salt structural styles, in W. Mohriak, and M. Talwani, eds., Atlantic rifts and continental margins: American Geophysical Union, Geophysical Monograph, 115, 129-149.

Mauduit, T., G. Guerin, J-P. Brun, and H. Lecanu, 1997, Raft tectonics : the effects of basal slope angle and sedimentation rate on progressive extension: Journal of Structural Geology, 19 (9), 1219-1239.

Mauduit, T., and J.-P. Brun, 1998, Growth fault/rollover systems: birth, growth, and decay: Journal of Geophysical Research, 103, 119-136.

Nelly, G., 1994, Evaporite sequences in petroleum exploration. 2. Geophysical Methods. GRECO52, CNR French Oil and Gas Industry Association, Technical Committee. Edition Technip, Paris, 252 pp.

Obone Zue Obame, E., V. Gaullier, F. Sage, A., Maillard, J. Lofi, B.C. Vendeville, I. Thinon, J-P. Réhault and the MAURESC Shipboard Scientific Party, 2011, The sedimentary markers of the Messinian Salinity Crisis and their relation with salt tectonics on the Provençal margin (Western Mediterranean): Results from the "MAURESC" cruise. Special Issue "Miocene-Pliocene geodynamics and paleogeography in the Mediterranean region: eustasytectonics interference": Bulletin de la Société Géologique de France, 182 (2), 181-196. 
Interpretation

Peel, F.J., 2014, The engines of gravity-driven movement on passive margins: Quantifying the relative contribution of spreading vs. gravity sliding mechanisms: Tectonophysics, 633, 126-142.

Quirk, D.G., N. Schodt, B. Lassen, S.J. Ings, D. Hsu, K.K. Hirsch, and C. Von Nicolai, 2012, Salt tectonics on passive margins: examples from Santos, Campos and Kwanza basins, , in G.I. Alsop, S.G. Archer, A.J. Hartley, N.T. Grant, and R. Hodgkinson, eds., Salt Tectonics, Sediments and Prospectivity: Geological Society, London Special Publications, 363, 207-244.

Roca, E., 2001, The Northwestern Mediterranean Basin (Valencia Trough, Gulf of Lions and Liguro-Provençal basins): structure and geodynamic evolution, in P.A. Ziegler, W. Cavazza, A.H.F., Robertson, and S. Crasquin-Soleau, eds., Peri-Tethyan Rift/Wrench Basins and Passive Margins 186, 671-706. Peri-Tethys Memoir, 6: Mémoires du Museum National d'Histoire Naturelle, Paris.

Roca, E., M. Sans, and L. Cabrera, 1999, Modelo tectonosedimentario del sector central septentrional del Margen Catalán sumergido (cubetas de Barcelona, Sant Feliu, Begur y Riumors-Rosas), in Libro Homenaje a José Ramírez del Pozo. AGGEP, Madrid, 199-217.

Roveri, M., M.A. Bassetti, and F. Ricci Lucchi, 2001, The Mediterranean Messinian salinity crisis: an Apennine foredeep perspective: Sedimentary Geology, 140, 201-214.

Roveri, M., S. Lugli, V. Manzi, and B.C. Schreiber, 2008, The Messinian Sicilian stratigraphy revisited: new insights for the Messinian salinity crisis: Terra Nova, 20, 483-488.

Rowan, M.G., F.J. Peel, and B.C. Vendeville, 2004, Gravity-driven foldbelts on passive margins, in K.R. McClay, ed., Thrust Tectonics and Hydrocarbon Systems:. AAPG Memoir, 82, $157-182$. 
Interpretation

Rowan, M.G., F.J. Peel, B.C. Vendeville, and V. Gaullier, 2012, Salt tectonics at passive margins: geology versus models - Discussion: Marine and Petroleum Geology, 37, 184-194.

Sans, M., and F. Sàbat, 1993, Oligocene salt rollers and syn-kinematic sediments in the northeast sector of the Valencia trough (western Mediterranean): Bulletin de la Societé Géologique de France, 164, 189-198.

Schettino, A. and E. Turco, 2010, Tectonic history of the western Tethys since the Late Triassic: GSA Bulletin, 123, 89-105.

Stamplfli, G.M. and C.F.W. Höcker, 1989, Messinian paleorelief from 3-D seismic survey in the Tarraco concession area (Spanish Mediterranean Sea): Geology in Mijnbouw, 68, 201-210.

Vendeville, B.C. and M.P.A. Jackson, 1992, The rise of diapirs during thin-skinned extension: Marine and Petroleum Geology, 9, 331-353.

\section{LIST OF FIGURES}

Figure 1. Idealized sketch of a salt-bearing passive margin with a basinward-dipping salt detachment (purple polygon) (modified from Rowan et al., 2004). Gravity gliding and spreading of the salt layer trigger the failure of the cover, which is accommodated by upslope extension (listric faults) and downslope contraction (buckle folds) with a translational domain in between. The factors controlling the tilting of the detachment are the differential loading, the thermal subsidence and the tectonic uplift. 
Interpretation

Figure 2. Simplified structural map of the Northwestern Mediterranean Basin and surrounding Mediterranean areas (modified from Roca, 2001). Yellow lines indicate the location of the geoseismic sections shown in Figures 3 and 4.

Figure 3. Line-drawing across the central part of the northwestern margin of the LiguroProvençal Basin (southeast of the Gulf of Lions) showing the structure and the sedimentary architecture of the basin infill (modified from Lofi et al., 2011b after Bache et al., 2009). See location in Figure 2.

Figure 4. Geoseismic sections across the toe of the northwestern part of the Liguro-Provençal Basin highlighting the gravitational failure structure around three pre-Messinian seamounts (vertical scale in TWTT, see location in Figure 2). They clearly illustrate how the structure of supra-salt units changes depending on the height and the slope of the flanks of pre-salt seamounts. a) Geoseismic section across a seamount with the summit located below the top of the Messinian salt that consequently did not affect the gravitational failure of the margin; b) Geoseismic section across a seamount with the summit located slightly above the top of the Messinian salt, and c) Geoseismic section across a much taller seamount with the summit that crops out on the seafloor. Note that the geometry of the reflectors in figures $4 \mathrm{a}, 4 \mathrm{~b}$ and $4 \mathrm{c}$ is congruent with that of the structures depicted in our analogue models 3 (Fig. 8b) and 6 (Fig. 13b) respectively.

Figure 5. Experimental setup with the terminology used in the description of the models. a) Topview sketch of the experimental setup with the location of the seamount and the different upslope pinch-out and downslope edge of the analogue evaporitic units; b) Longitudinal cross-section sketch of the setup before deformation (the height of the plasticine seamount " $h$ " changes in our 
experimental programme; see Table 1); and c) Experimental stratigraphy with the strength curve and equivalence with the sedimentary ifill in the deep Liguro-Provençal Basin.

Figure 6. Comparison between the main structural elements developed by gravitational gliding at the end of the deformation in a cross-section of the experiment without a seamount (experiment 0 , Table 1) (a); in a cross-section of the experiment 1a cutting a seamount with the summit located inside the pure polymer layer (b); and (c) in a cross-section of experiment 4 (Table 1) that cuts a seamount with the summit located above the top of the pure polymer layer. LU: Mixed pink polymer and sand (50\% by volume) representing the Messinian Lower Unit; MU: pure transparent polymer that simulates de Messinian Mobile Unit.

Figure 7. Detailed cross-sections showing the main structures developed around the seamount during gravitational gliding when the summit is initially located inside the pure polymer layer. a) Cross-section of experiment 1 (Table 1) after 6 hours of gravitational gliding, b) cross-section of experiment 1a (Table 1) after 18 hours of gravitational gliding. Note that the pure polymer layer shows thickness variations, whereas the pink layer (mixture of sand and polymer) does not show any deformation.

Figure 8. Detailed cross-sections showing the main structures developed around the seamount during gravitational gliding before (a) and after (b and c) polymer overthrusting. a) Cross-section of experiment 4 after 6 hours of gravitational gliding, b) Cross-section of experiment 3 after 18 hours of gravitational gliding, and c) Cross-section of experiment 7 after 34 hours of gravitational gliding. Note that in Figures $7 \mathrm{~b}$ and $7 \mathrm{c}$, the pink layer (mixture of sand and polymer) appears deformed downslope of the seamount, where it is thinner beneath the welded areas and thicker in the adjacent inflated areas. 
Interpretation

Figure 9. a to h) Top view pictures draped over the colored relief surfaces created from the corresponding topography point cloud from the beginning $\left(t_{0}\right)$ to the end $\left(t_{16}\right)$ of experiment $\left.3 ; i\right)$ Evolution of the topography along the cross-section a-a' during experiment 3 between $t_{0}$ to $t_{16}$. The figures show two evolutionary stages: the first one between $t_{0}$ and $t_{4}$, characterized by the progressive rising of the polymer and overlying cover above the upslope flank of the seamount and the presence of two extensional-contractional pairs separated by the seamount; and the second one between $t_{6}$ and $t_{16}$ in which the previously rising polymer overthrusts the seamount and begins to slide down on the downslope seamount flank forming a gravitationally linked fold and thrust system. During this second stage the two extensional-contractional pairs are reconnected.

Figure 10. Slices of experiment 3 made from a $3 \mathrm{D}$ voxel that used the final serial sections as a seed to interpolate sections in every direction (see Dooley et al., 2009). a and b) Inlines that correspond to real end sections; c) Interpolated depth slice; and d, e, f and g) Interpolated crosslines. The location of each section is shown in different colors in each image (inlines in blue; crosslines in purple; and depth slice in yellow). Blue, red and green colors inside the pure polymer correspond to the deformed polymer color plugs.

Figure 11. Detail of a cross-section of experiment 3 showing the structure of the downslope flank of the seamount after 18 hours of gravitational gliding and its correlation with the proposed evolutionary stages The development of debrites is highlighted during the progressive rising of the polymer at the upslope flank of the seamount and during the overthrusting coeval with the development of the erosive unconformity. Debrite deposits decrease progressively through time, disappearing with the deposition of layer 6 . 
Figure 12. Top-view photograph (a) and longitudinal cross-section (b) showing the main structural elements related to the highest seamount (experiment 6, Table 1). The overhead photograph was taken after 4 hours of gravitational gliding and prior to the deposition of the upper red layer in Fig. 12b.

Figure 13. a) Contour map of the top of the pure polymer at the end of experiment 3 . The reference datum of this map ( 0 value) is the top of the last syn-kinematic sand layer (see Fig. $8 b)$. b) The top view of the pure polymer layer in model 3 at the end of the experiment shows the effect of the seamount on the pure polymer flow and on the deformation of the colored polymer plugs. Welds, diapirs and the final shape of the polymer plugs were reconstructed by digitizing their position and edges on different depth slices (i.e., in the depth slice represented in Figure 10c). c) Interpreted cross-section through the seamount showing the shape of two polymer plugs (purple and yellow) at the end of model 3.

Table 1. Main experimental parameters for the physical models described in this article. ${ }^{*}$ The slope angle corresponds to the value of the average angle of the seamount flanks.

Table 2. Scaling parameters used in the experimental program presented in this study. 


\section{Page 39 of 53}

Interpretation

1

2

3

4

5

6

7

8

9

10

11

12

13

14

15

16

17

18

19

20

21

22

23

24

25

26

27

28

29

30

31

32

33

34

35

36

37

38

39

40

41

42

43

44

45

46

47

48

49

50

51

52

53

54

55

56

57

58

59

60

Table 1. Experimental program

\begin{tabular}{l|c|c|c}
\hline Experiment & $\begin{array}{c}\text { Seamount height } \\
(\mathrm{mm})\end{array}$ & $\begin{array}{c}\text { Slope } \\
\text { angle * }\end{array}$ & $\begin{array}{c}\text { Time } \\
\text { (hours) }\end{array}$ \\
\hline Exp._0 & no seamount & - & 6 \\
Exp._1 & 21 & $23^{\circ}$ & 6 \\
Exp._1a & 21 & $23^{\circ}$ & 18 \\
Exp._2 & 28 & $29^{\circ}$ & 18 \\
Exp._3 & 35 & $35^{\circ}$ & 18 \\
Exp._4 & 35 & $35^{\circ}$ & 6 \\
Exp._5 & 45 & $42^{\circ}$ & 6 \\
Exp._6 & 55 & $48^{\circ}$ & 6 \\
Exp._7 & 35 & $35^{\circ}$ & 34 \\
\hline \multicolumn{2}{c}{ *Average slope angle of seamount flanks }
\end{tabular}

* Average slope angle of seamount flanks 
Table 2. Scaling parameters used in the experimental program

\begin{tabular}{|c|c|c|c|}
\hline Quantity & Experiment & Nature & Ratio \\
\hline \multicolumn{4}{|l|}{ Thickness } \\
\hline Overburden & $5-30 \mathrm{~mm}$ & $300 \mathrm{~m}-2 \mathrm{~km}$ & $1.6 \times 10^{-5}-1.5 \times 10^{-5}$ \\
\hline Upper Messinian Unit & $6 \mathrm{~mm}$ & $500-600 m$ & $1.09 \times 10^{-5}$ \\
\hline Mobile Messinian Unit & $10 \mathrm{~mm}$ & $0-3 \mathrm{~km}$ & $1.8 \times 10^{-5}$ \\
\hline Lower Messinian Unit & $5 \mathrm{~mm}$ & $400-500 m$ & $1.1 \times 10^{-5}$ \\
\hline \multicolumn{4}{|l|}{ Density } \\
\hline Overburden & $1500 \mathrm{~kg} \mathrm{~m}^{-3}$ & $2.300 \mathrm{~kg} \mathrm{~m}^{-3}$ & 0.65 \\
\hline Upper Messinian Unit & $1500 \mathrm{~kg} \mathrm{~m}^{-3}$ & $2.600 \mathrm{~kg} \mathrm{~m}^{-3}$ & 0.57 \\
\hline Mobile Messinian Unit & $972 \mathrm{~kg} \mathrm{~m}^{-3}$ & $2.200 \mathrm{~kg} \mathrm{~m}^{-3}$ & 0.46 \\
\hline Lower Messinian Unit & $1550 \mathrm{~kg} \mathrm{~m}^{-3}$ & $2.600 \mathrm{~kg} \mathrm{~m}^{-3}$ & 0.59 \\
\hline \multicolumn{4}{|l|}{ Density contrast } \\
\hline$U U / M U$ & 528 & 500 & 1.05 \\
\hline$M U / L U$ & 578 & 500 & 1.56 \\
\hline \multicolumn{4}{|l|}{ Ductile layer viscosity } \\
\hline Mobile Messinian Unit & $1.6 \times 10^{-4} \mathrm{~Pa} \mathrm{~s}$ * & $10^{-18}-10^{-19} \mathrm{~Pa} \mathrm{~s}$ & $1.6 \times 10^{-14}-1.6 \times 10^{-15} \mathrm{~Pa} \mathrm{~s}$ \\
\hline Lower Messinian Unit & $3.34 \times 10^{-4} \mathrm{~Pa} \mathrm{~s}^{*}$ & unkown & -- \\
\hline $\begin{array}{l}\text { Overburden coefficient } \\
\text { of internal friction }\end{array}$ & 0.69 & 0.8 & 0.86 \\
\hline Gravity acceleration & $9.81 \mathrm{~m} \cdot \mathrm{s}^{-2}$ & $9.81 \mathrm{~m} \cdot \mathrm{s}^{-2}$ & 1 \\
\hline
\end{tabular}

* Viscosity measured when deformed at a laboratory strain rate of $1.83 \times 10^{-4} \mathrm{~cm} \mathrm{~s}^{-1}$ 


\section{Page 41 of 53}

Interpretation

1

2

3

4

5

6

7

8

9

10

11

12

13

14

15

16

17

18

19

20

21

22

23

24

25

26

27

28

29

30

31

32

33

34

35

36

37

38

39

40

41

42

43

44

45

46

47

48

49

50

51

52

53

54

55

56

57

58

59

60

https://mc.manuscriptcentral.com/interpretation 


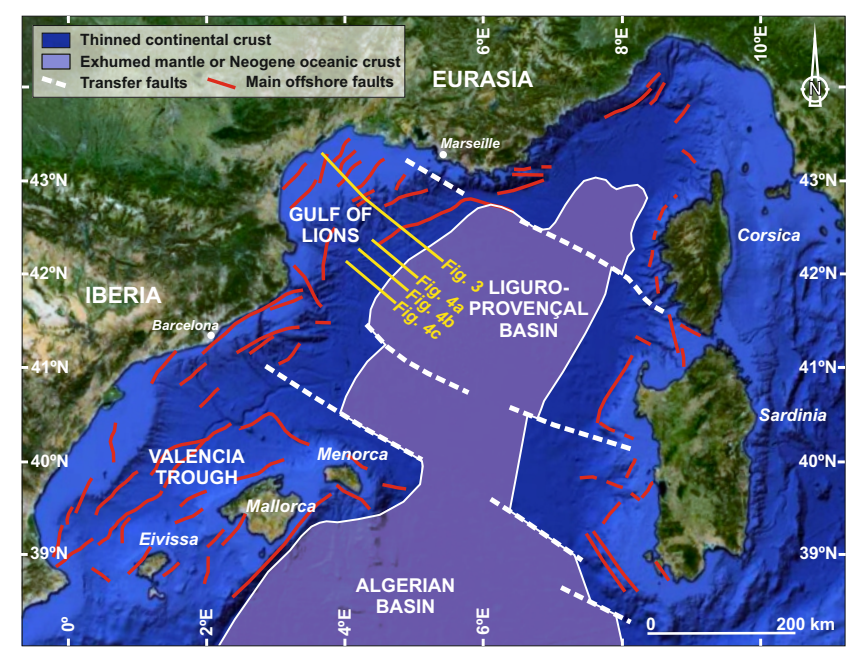

Figure 2 


\section{Page 43 of 53}

\section{Interpretation}

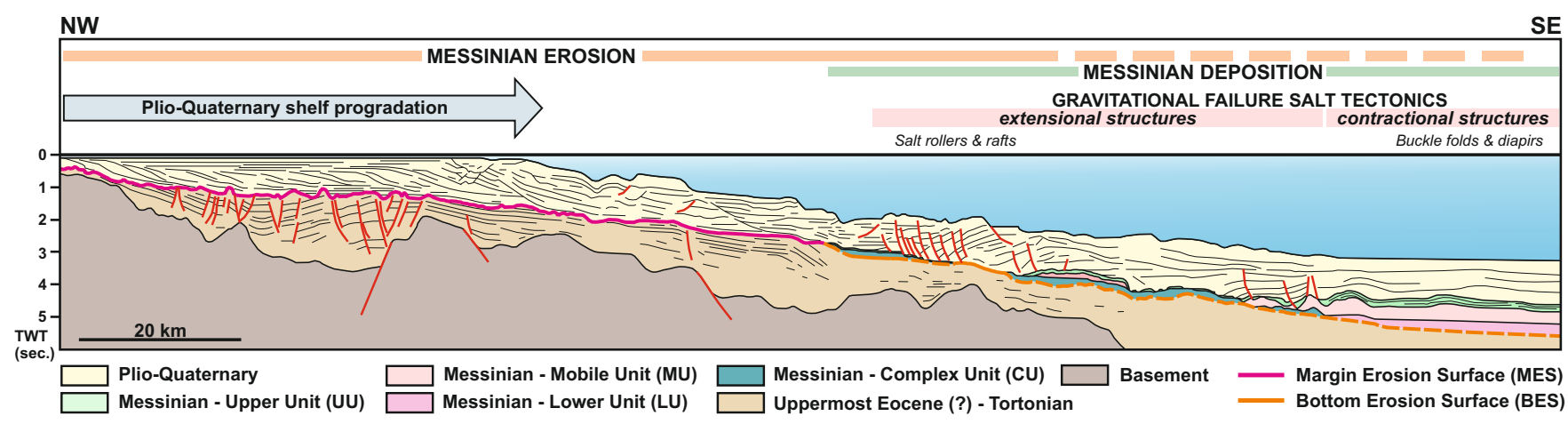

Figure 3 

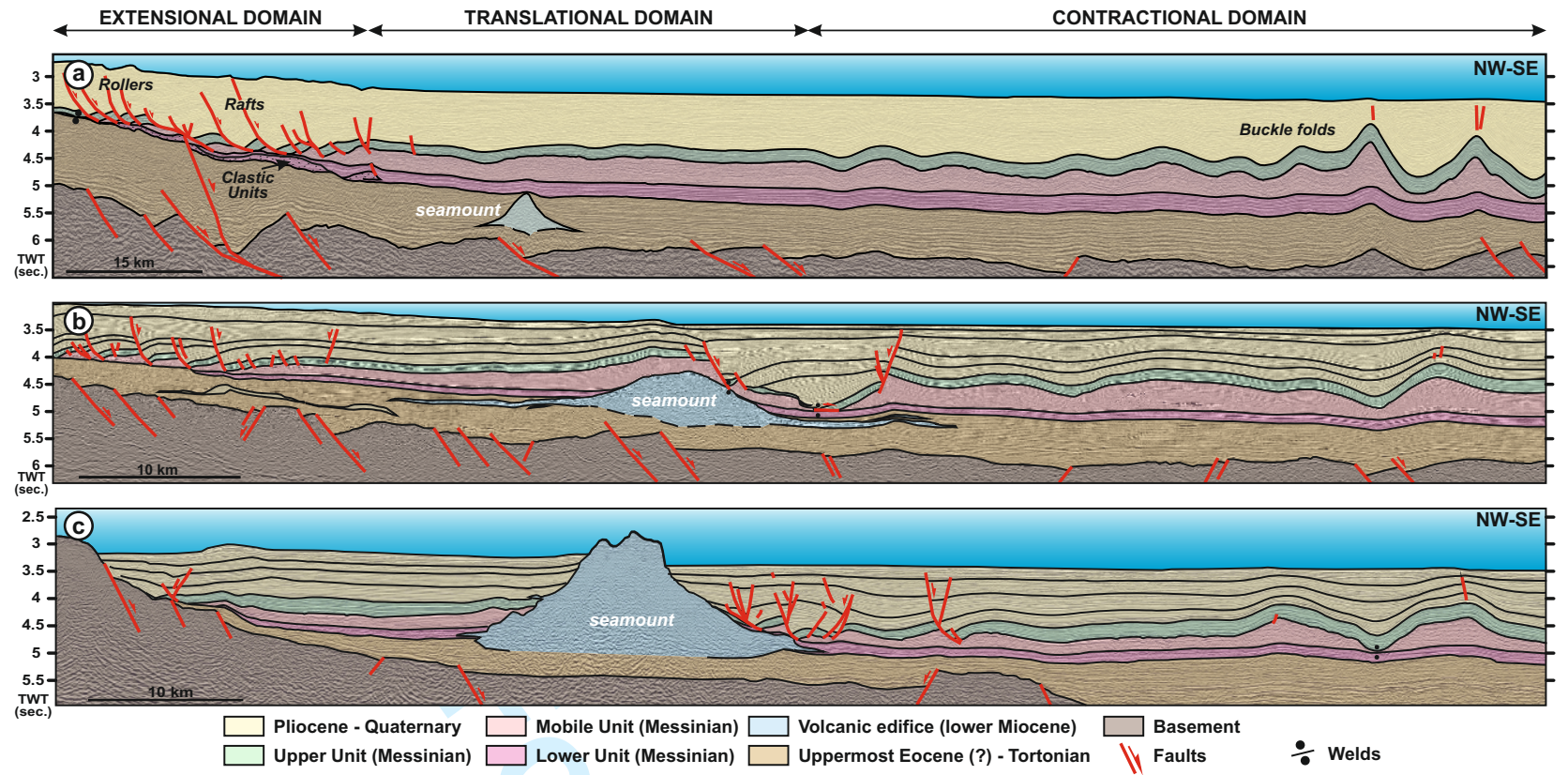

Figure 4 
a) Experimental setup plan view without Messinian analogues

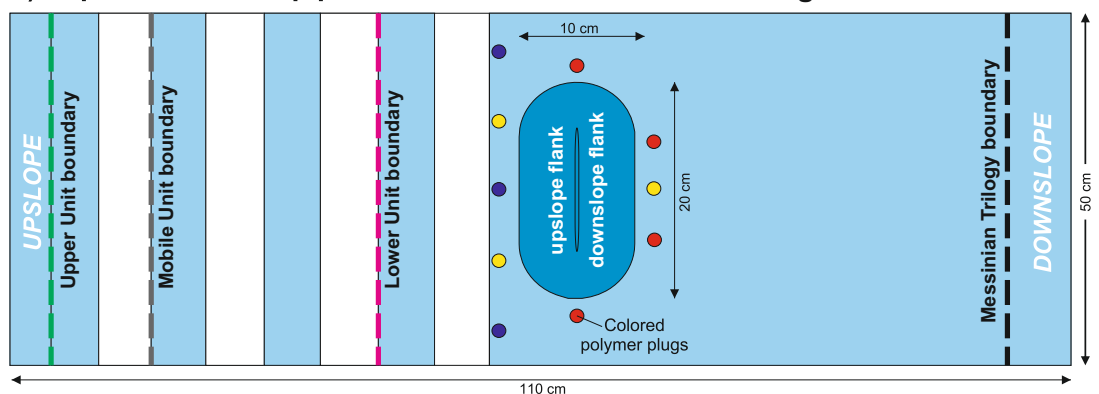

b) Experimental setup section view

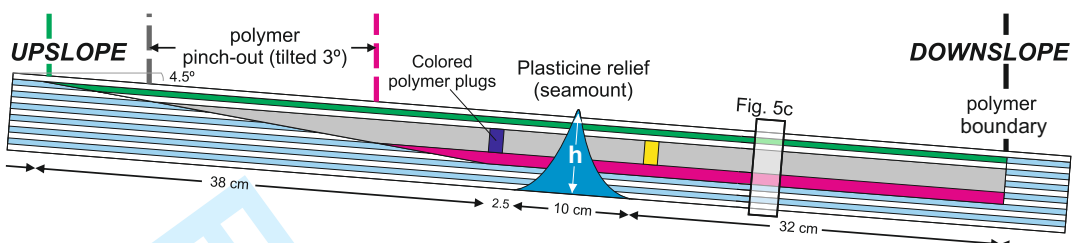

c) Seismic and experimental stratigraphy

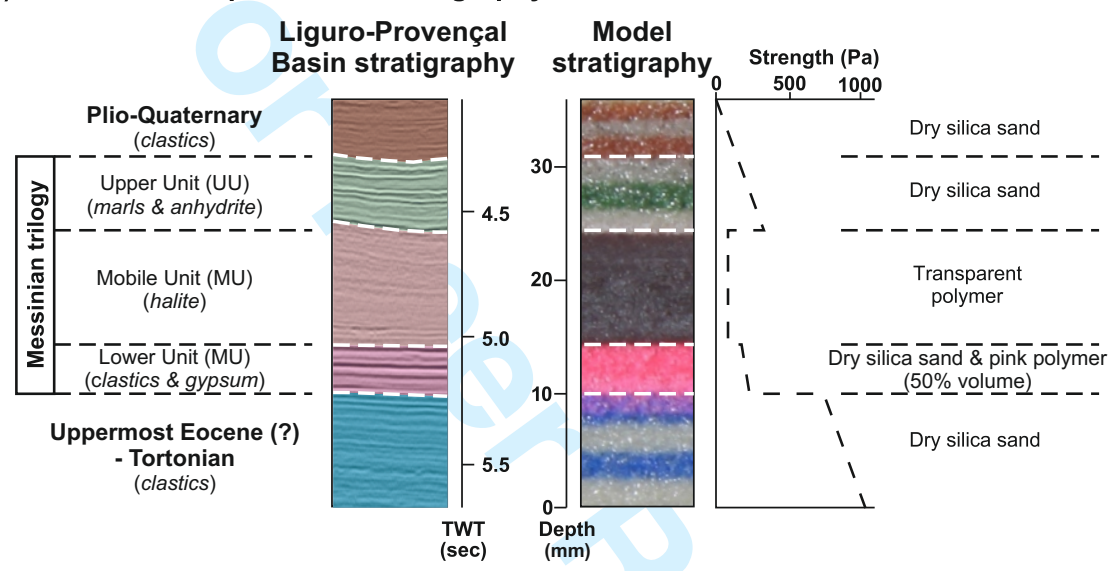

Figure 5 
a) Gravitational failure geometry without seamount (baseline model - Exp. 0) Upslope extensional

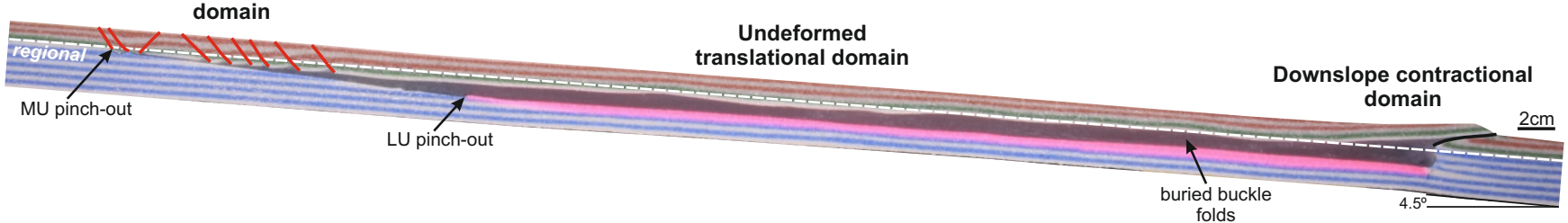

b) Gravitational failure geometry with seamount summit inside the pure polymer layer (Exp. 1a)

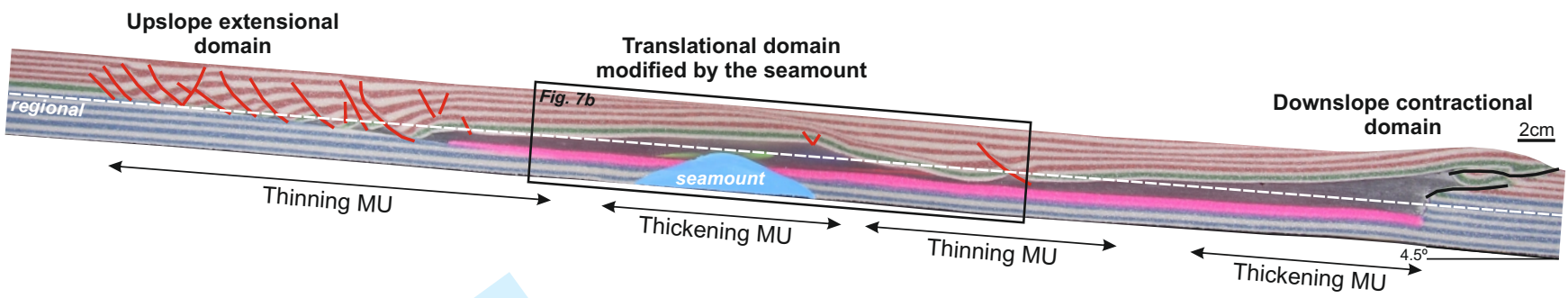

c) Gravitational failure geometry with seamount summit above the pure polymer layer (Exp. 4)

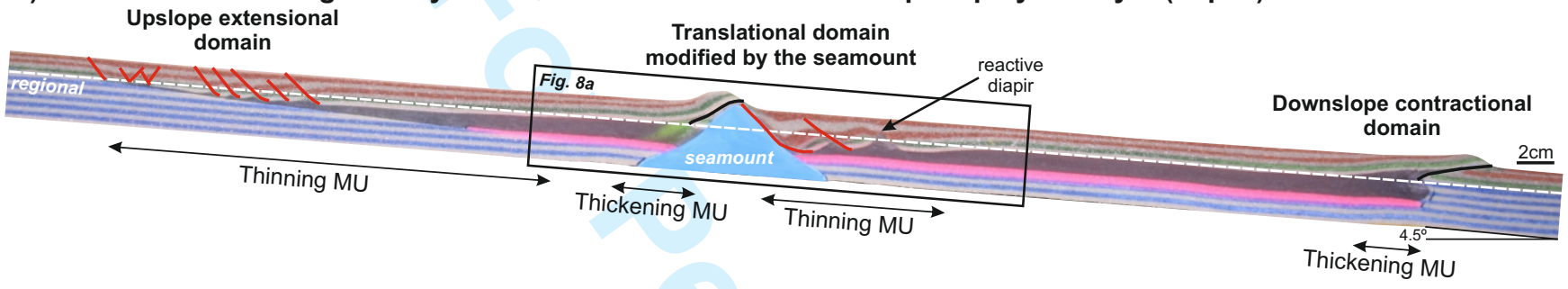

Figure 6 
a) Seamount detail after 6 hours of gravitational failure (Exp. 1)

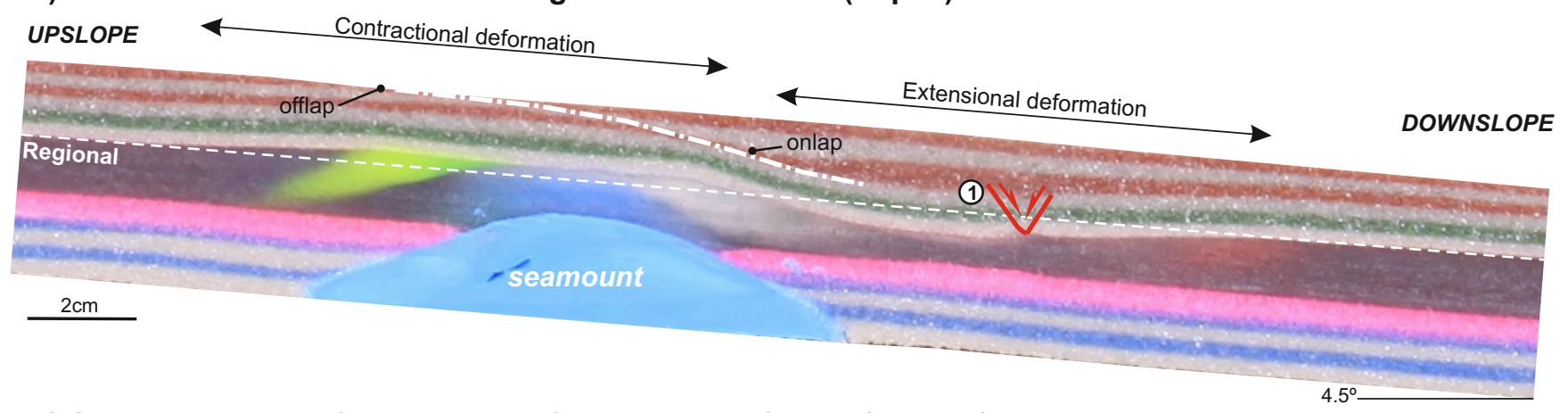

b) Seamount detail after 18 hours of gravitational failure (Exp. 1a)

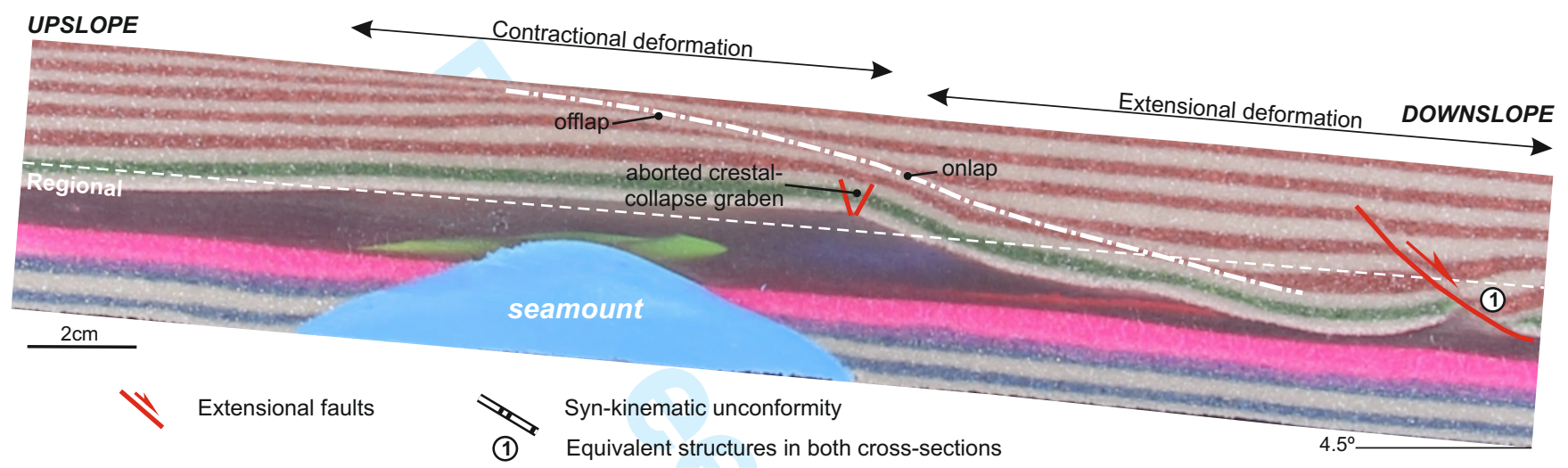

Figure 7 
b) Seamount detail after 18 hours of gravitational failure (Exp. 3)

a) Seamount detail after 6 hours of gravitational failure (Exp. 4)
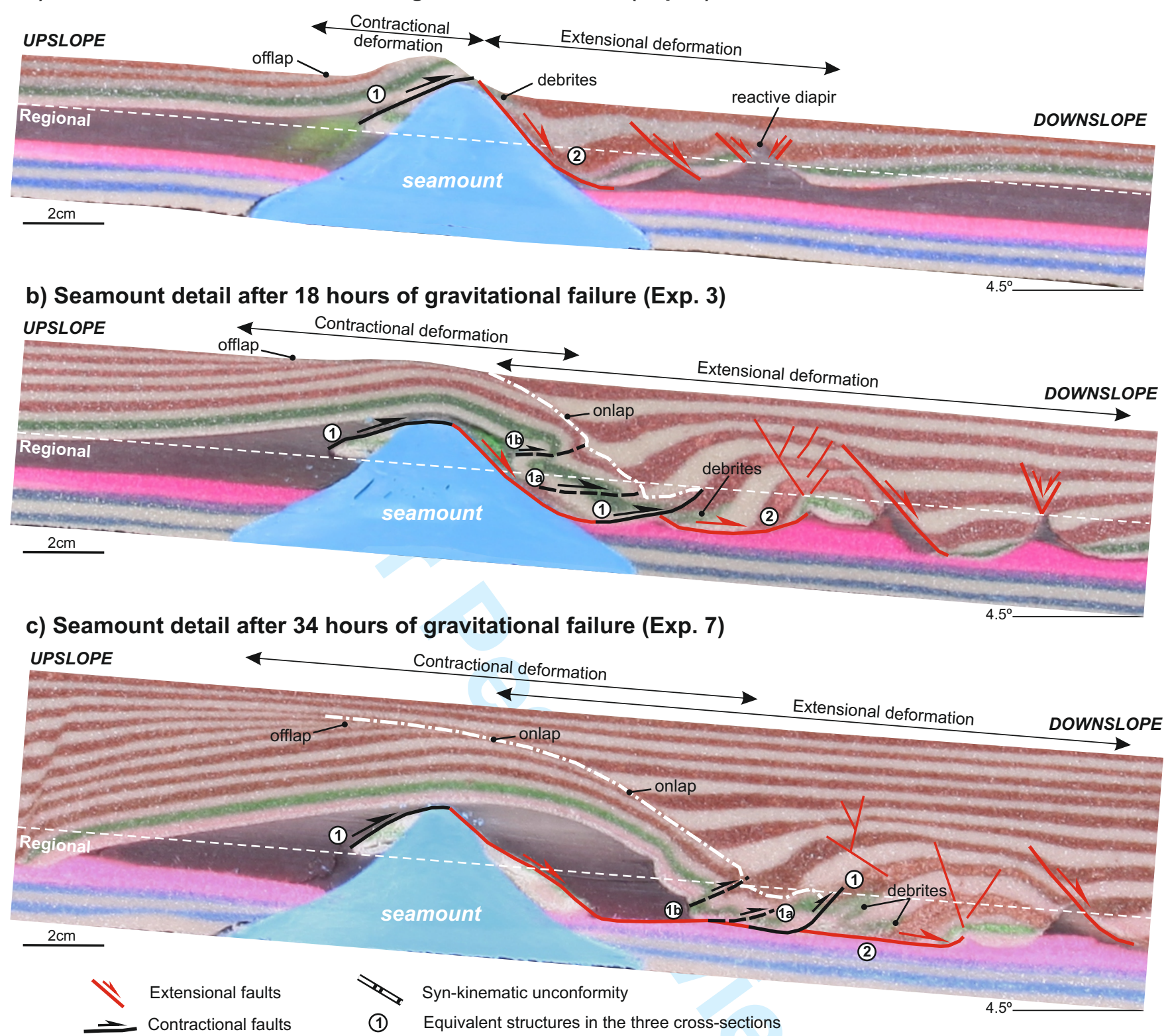

Figure 8 


\section{Page 49 of 53}
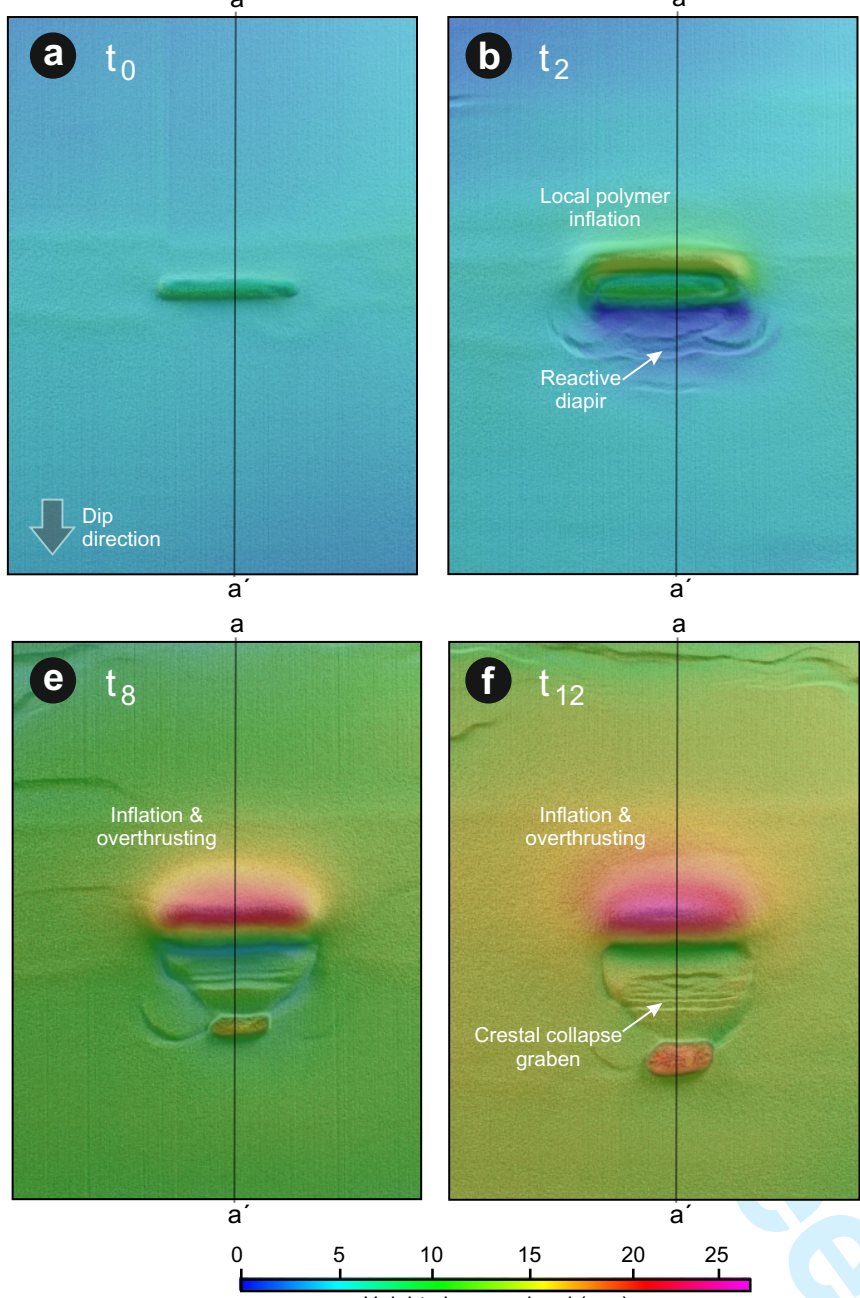

(i)
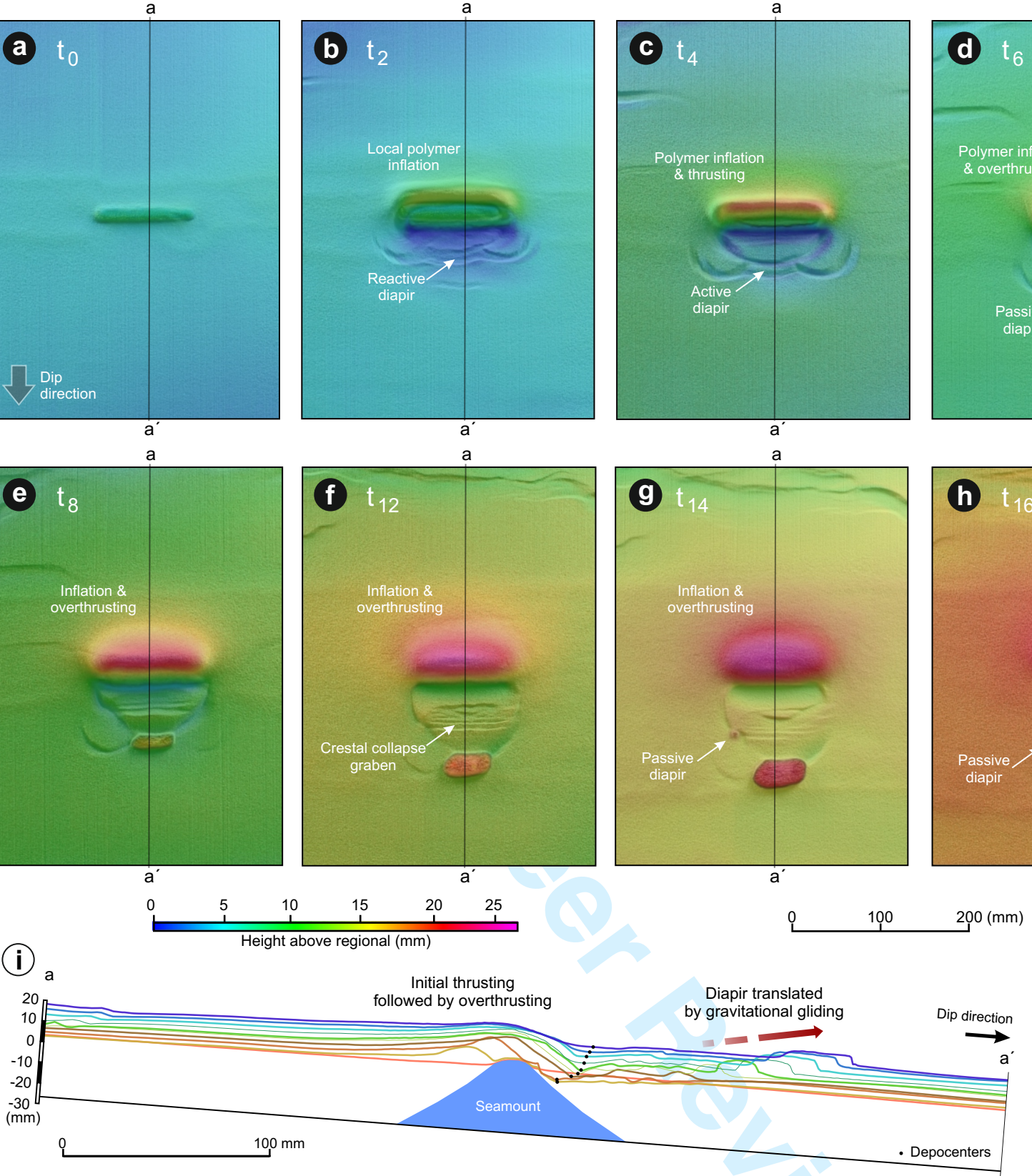
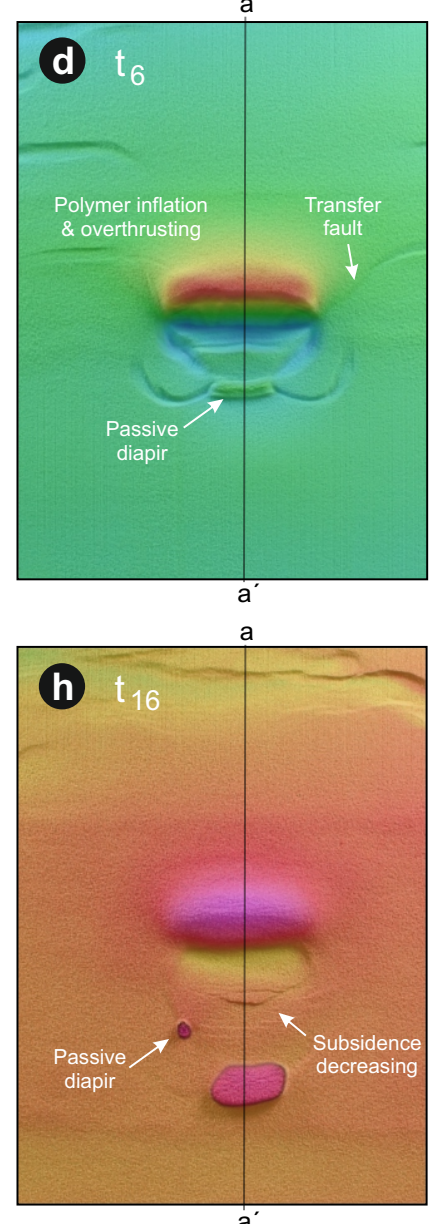

$$
\begin{aligned}
& t_{16}-t_{6}- \\
& t_{14}-t_{4}- \\
& t_{12}-t_{2}- \\
& t_{8}-t_{0}-
\end{aligned}
$$

Figure 9 


\section{Inlines}

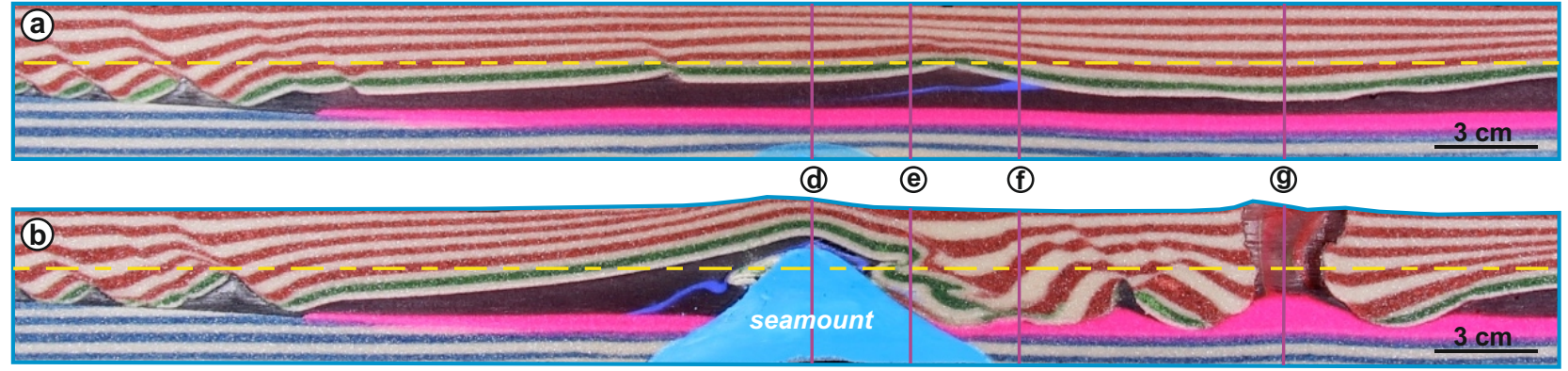

\section{Depth slice}

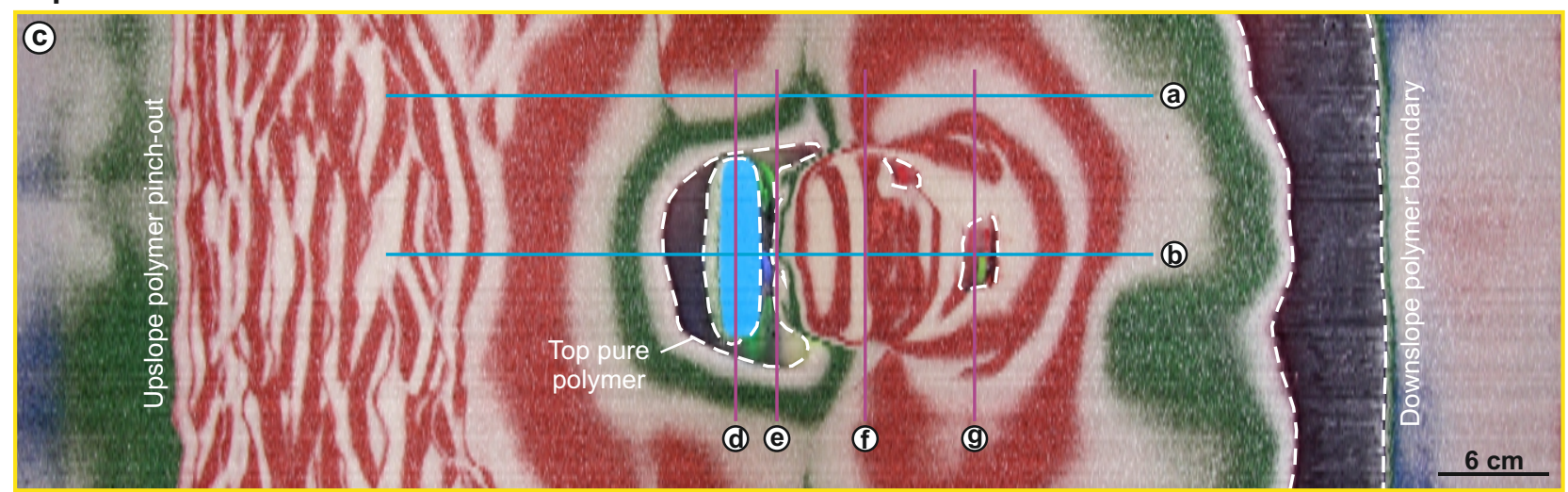

\section{Crosslines}

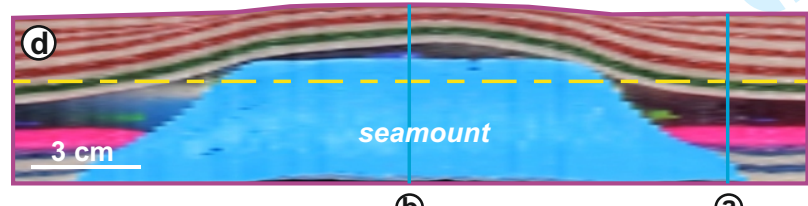

(D)

(a)
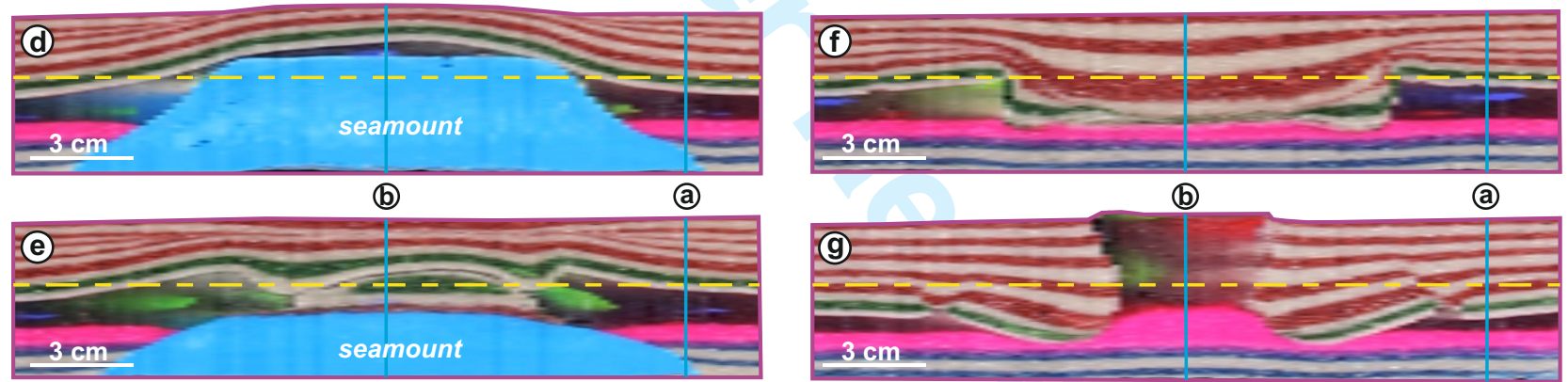

(b)

(a)

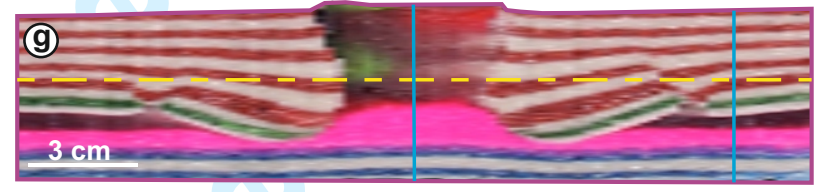

Figure 10 

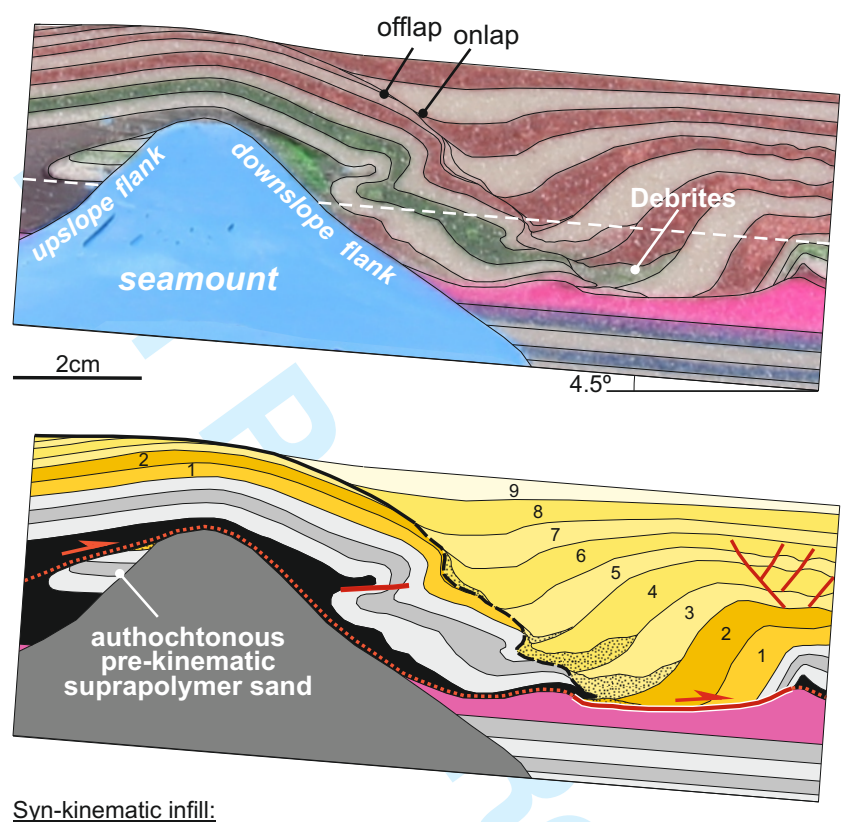

Syn-kinematic infill:

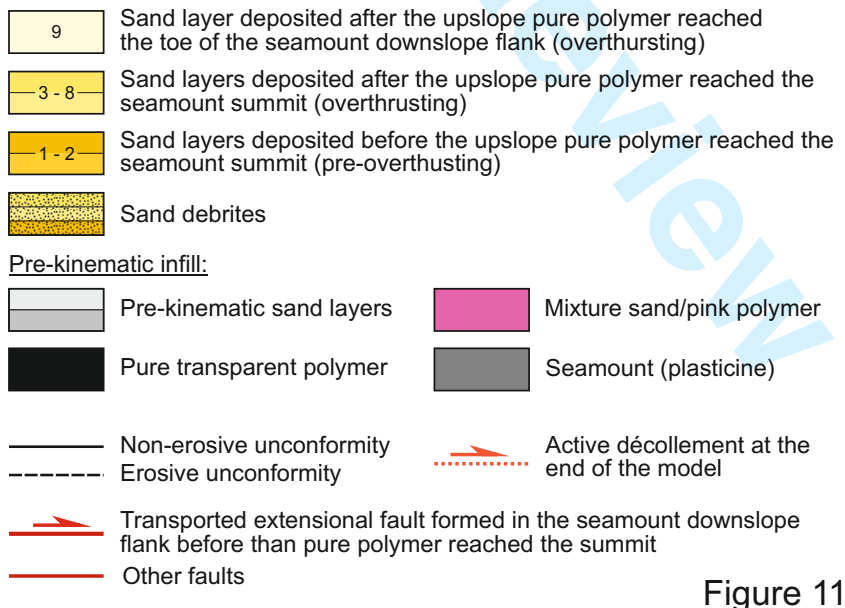




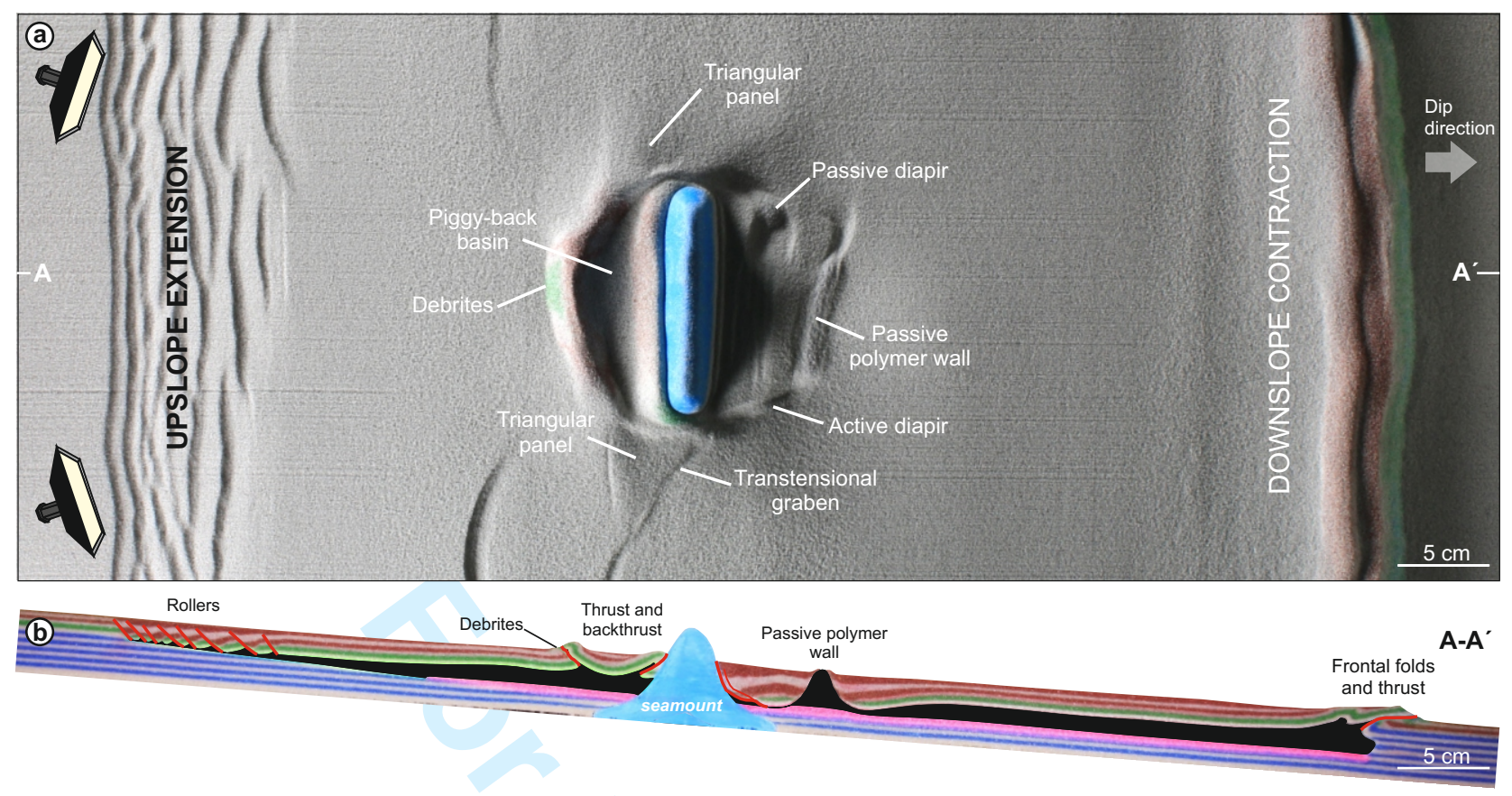

Figure 12 


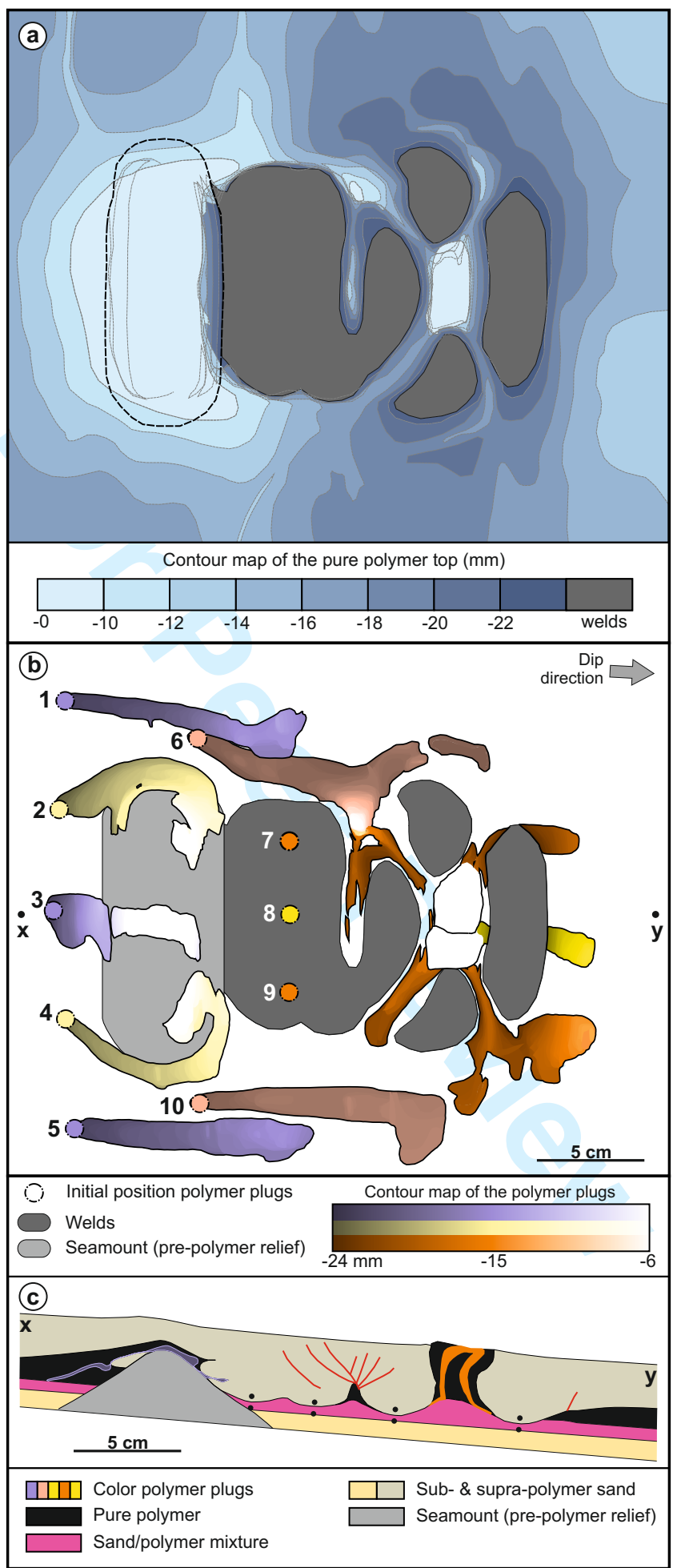

Figure 13 